\title{
Food, Sex and Death: Cosmologies in the British Iron Age with Particular Reference to East Yorkshire
}

\author{
Mike Parker Pearson
}

The British Iron Age had an enduring set of traditions involving the east-west axis of the sun's path, the sunwise progression of movement and the classification of animals. Although these traditions were manifested regionally in slightly different ways and were modified, contested and restructured during the Iron Age, they provide us with a key to unlock aspects of the symbolism and practices of daily life. The significance of westerly orientations and of pigs in embodying and expressing associations of high status and other social differences were principal features of a strongly hierarchical society whose social differences were otherwise largely muted in terms of material culture distinctions. The cemeteries of East Yorkshire provide a detailed insight into the ordering of these social differences which were, even then, only rarely expressed through grave goods and mortuary elaboration. The burials of the Yorkshire élite are suggestive of a conception of sacred leadership or kingship, which included the symbolic spearing of certain individuals. Animal offerings were used in the structuring of social differences, with pig portions and sheep bones marking the.dead of élite and commoner groups respectively.

The reconstruction of prehistoric cosmologies and attitudes to the body is an area of research which has benefited considerably from structuralist and poststructuralist theoretical perspectives. This case study is an attempt to identify the underlying rules which structured human experience during the pre-Roman Iron Age of the British Isles, by applying these theoretical approaches to evidence which is largely archaeological in its origin. The act of decoding prehistoric material remains relies to a large extent on the accessibility of different forms of material expression; in this case, architecture and settlement layout, human burials, animal burials, artistic depictions, portable artefacts, and their spatial, contextual and topographical inter-relationships.

\section{Orientation - facing east in life and death}

Our entry point to understanding the British Iron Age is to appreciate how people were oriented in their daily lives and how, through the 'natural symbolism' of their bodies, they classified and acted in the world. We approach this problem by examining the use of space in terms of house, compound and cemetery organization, particularly in the provision of gateways and doorways (Parker Pearson \& Richards 1994b), thereby understanding the orientations of people's movements in relation to the built spaces of house and tomb.

Throughout Britain, the roundhouses which characterize the Iron Age share a consistent set of orientations, with few exceptions, during the period from the Late Bronze Age after c. $900 \mathrm{BC}$ until the first century AD (Parker Pearson 1996). The majority of house entrances are orientated towards the east and southeast (Fig. 1), not so as to provide optimal sunlight or shelter from the wind but so that their doorways might be aligned on sunrise at the equinoxes or at midwinter (Oswald 1997). Most of the exceptions plotted by Oswald fall somewhere between 


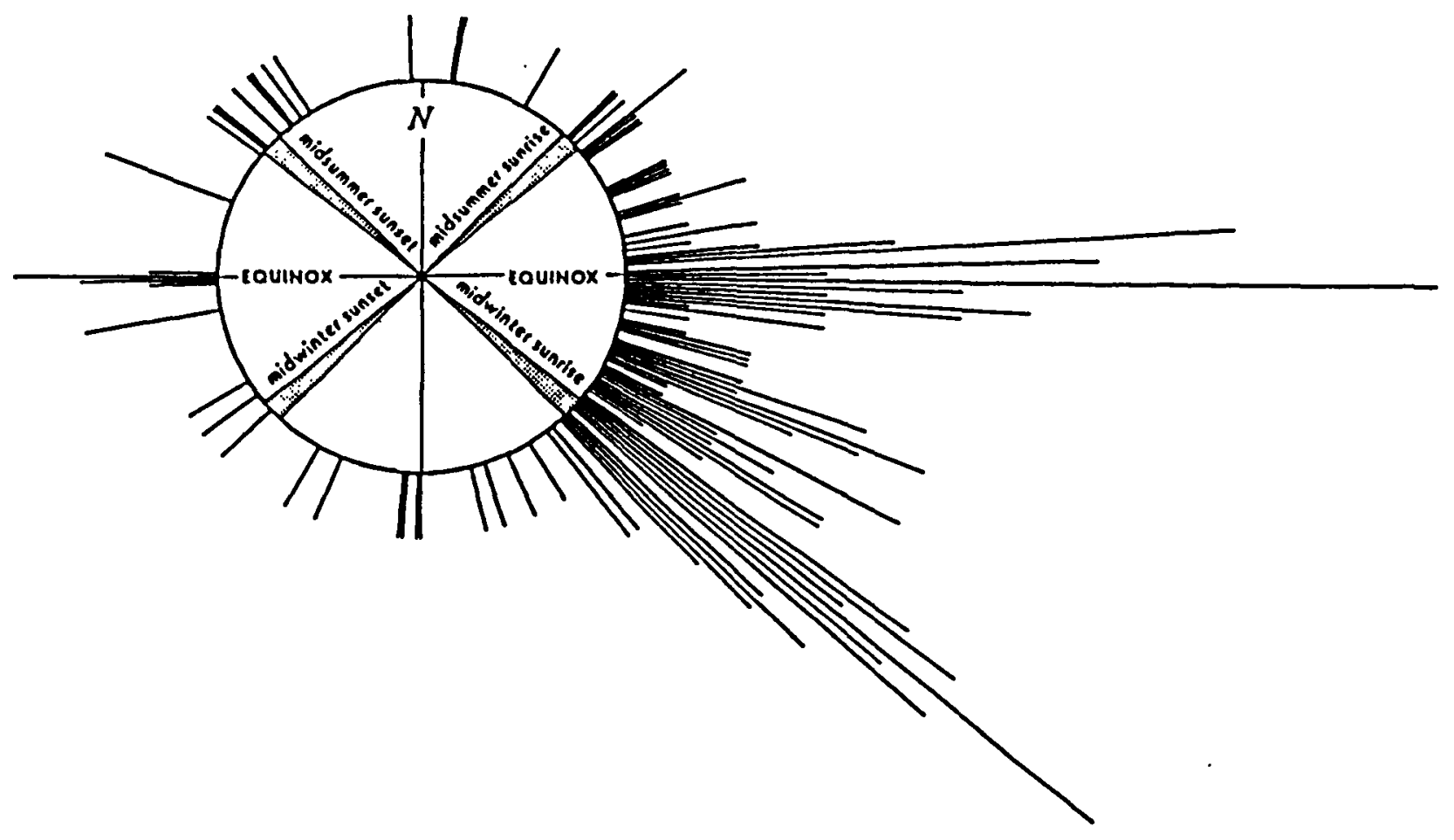

Figure 1. Orientations of British Iron Age roundhouses. (From Oswald 1997, with permission from the author and Oxbow Books.)

due east and southeast. This concern with the directionality of entrances is also found in the gateways to the settlement compounds and enclosures. The majority of these face broadly east or broadly west, or both. In southern Britain, the largest enclosures, 'hillforts', usually have two entrances, one facing east and the other west. Most inhumation burials were laid out with the corpse facing east (Whimster 1981), the same direction as the entrances of houses and settlements. Of course, the underrepresentation of burials throughout the British Iron Age restricts the geographical scope of this generalization to areas such as East Yorkshire, the Southwest and Wessex where more than the occasional inhumation has been found.

The Iron Age individual, standing in the doorway of a house and looking out, was oriented (literally 'facing east'). The east was forwards, the north left, the south right and the west behind (Parker Pearson 1996). ${ }^{1}$ Why there was a difference between selection of due east and southeast is unclear. Did it result from regional or chronological differences, or was it dependent on the time of year of construction?

The archaeological origins of this orientational concern with the east and southeast can be traced back to the Later Bronze Age. The large circular monument at Thwing on the Yorkshire Wolds contains, at its centre, a large circular post structure thought to be a roofed building but which might possibly be just a timber ring in association with a deposit of animal bones derived from feasting (Manby 1986; Graham Mounteney pers. comm.). The outer enclosure and the inner structure are both orientated on an axis facing towards the southeast. ${ }^{2}$ Associated metalwork apparently dates to the thirteenth-eleventh centuries $\mathrm{BC}$, placing the construction of this remarkable building many centuries before the widespread adoption of the easterly/southeasterly axis in roundhouses. Other examples of 'ringforts' like Thwing are found in the Thames estuary at Mucking North and South Rings, Highstead and Springfield Lyons (Champion 1980; Buckley \& Hedges 1988). In several of these cases, dating to around $900 \mathrm{BC}$, the main entrance of both buildings and enclosures faces due east. Such complexes can be interpreted as residences but they may also or instead have functioned as sacred structures. In this vein it is worth considering the growing permanence and monumentality of the domestic roundhouse from the Middle Bronze Age onwards, perhaps providing a new focus for social activities within the house rather than outside it. We may speculate that these increasingly solid and longer-lasting buildings became increasingly the residences not only of the living but also of the ancestors. Where ground plans of other Later Bronze Age houses have been recovered, their orientations are mainly towards the south-southwest. Whether this was to maximize sunlight within the house and minimize the impact of westerly and easterly winds, or whether it embodied cosmological logics beyond practical reasoning, is not established.

\section{Westward orientations and social difference}

It is likely that, within Britain, there were regional variations in this 'orienting of the body', and I have suggested that 'west' was an inauspicious, death- 
linked direction in the Iron Age of Wessex and southern England (Parker Pearson 1996; see also Gwilt 1997, 164-5). I now believe, however, that the evidence can be better understood within the supra-regional perspective that broadly west-facing houses were also demonstrations of social difference, perhaps residences of local élites or of other segregated groups in Iron Age society. The effect of this reversal is not to associate this differential status with west/behind but, in fact, to link such personages with the propitious east/front since they would occupy the east of the house and be approached by others through the door from the west.

This cosmological grid is not without its subtleties and anomalies. In addition to the majority of eastward-looking doorways, there is a small but significant proportion of broadly west-facing entrances. The wetland settlement of Glastonbury lake village departs from the norm of east-facing houses in having not only a wide range of doorway orientations but also a number of west-facing doorways at its core (Coles \& Minnitt 1995, figs. 4.9-4.12). It may have been just a normal settlement, but its range of artefacts and its border location render its identification as a normal settlement uncertain (Coles \& Minnitt 1995, 207). In similar vein, more than half of the inhabited stone round towers (brochs) of western and northern Scotland have a westerly-facing doorway (Fig. 2), in contrast to most of the ordinary roundhouses of that region (Parker Pearson et al. 1996). These broch towers, requiring considerable labour mobilization in their construction, may be considered to have been the dwellings of local overlords which were placed in boundary zones between roundhouse communities (Parker Pearson \& Sharples 1999). Conversely, the fact that many brochs face east is probably a measure of how the association of orientation and status was not a cultural absolute within the Atlantic Scottish Iron Age, let alone the whole of Britain, but was subject to local and contextual interpretation. The distinction of eastern and western entrances and their status associations is also recognizable in the Wessex Iron Age (Fig. 3).

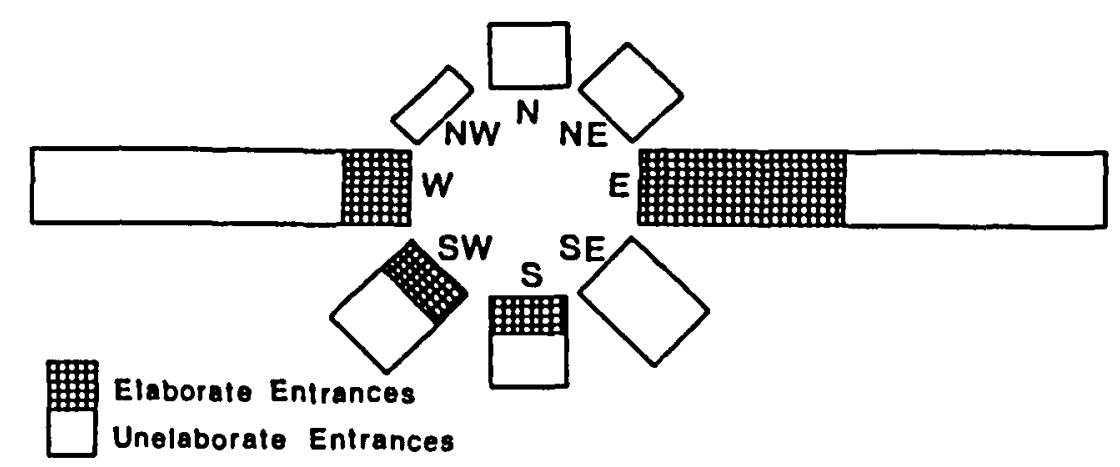

Figure 3. Orientations of 75 hillfort and 139 nonhillfort entrances in Iron Age southern Britain. (From Hill 1996 with permission from the author and Sheffield Academic Press.)

The majority of non-hillfort enclosure entrances - face east or southeast whereas hillfort entrances tend to face both east and west (Hill 1996, figs. 8.9 \& 8.10). Indeed, hillforts commonly comprise both an eastern and a western entrance within their earthworks. 


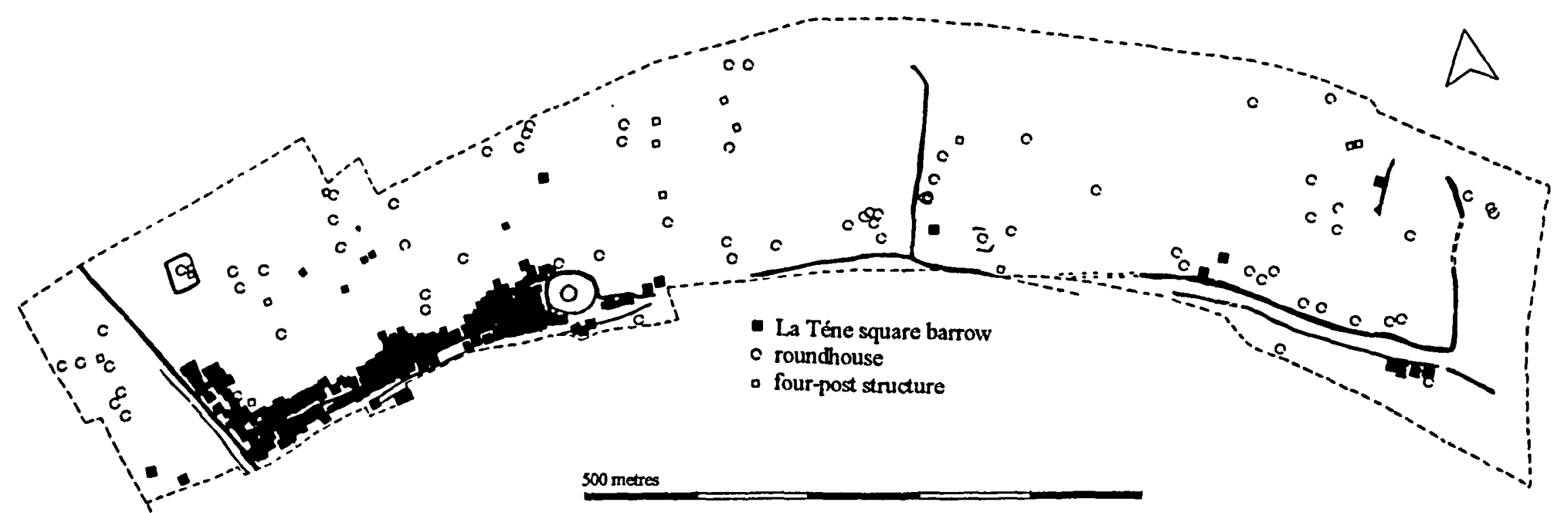

Figure 4. A plan of the Iron Age settlement and cemetery at Wetwang Slack. The southwest-facing house is located in the centre of the excavated area, about 200 m northeast of the east end of the main cemetery area and is surrounded by 'four-posters'. (From Dent 1983 with permission from the author and the East Riding Archaeological Society.)

Another potential association of a westerly entrance with a high-status roundhouse is at the Iron Age settlement and cemetery at Wetwang Slack in east Yorkshire (Dent 1983, fig. 3), where one building, isolated in the central area where the four-posters (putative granaries) are located, has its doorway to the southwest, in contrast to the easterly doors of the other houses (Fig. 4). There are further indications that west-facing doorways may also have marked other kinds of difference by which groups other than the élites may have expressed their identities. For example, the Hebridean wheelhouses of Cnip (Armit 1996, 136-43), Allasdale (Young 1953) and Clettraval (Scott 1948) all face westwards. Whereas Cnip may have been differentiated for its associations with metalworking (Armit \& Dunwell 1992), the reasons for the others' orientations are not apparent.

There are regions such as North Wales where there seems to have been no such concern with establishing east-facing doorways (Oswald 1997). Regional groups often subvert or oppose dominant belief systems as a means of expressing their autonomy and exclusion. Thus we should not be surprised that there are not only specific settlements, such as Glastonbury, but also particular regions, such as North Wales, where the emphasis on easterly orientation is lacking. Equally, we must also be prepared to accept that the use of broadly west-facing doorways will have been subject to regional vagaries and local resistances. Structuring principles such as cosmological orientation are also honoured in the breach and we should not expect our model to be without its anomalies and differences.

\section{Pigs and social status}

Along with facing west, a further commonly used mark of social difference throughout the British Iron Age may have been the totemic significance of the pig as a high-status feasting food. The treatment of pig remains appears to have varied considerably throughout Britain but it has regional manifestations which indicate variations on a common theme of the pig as status symbol. In the Scottish brochs, not only are pigs more frequent components of the mammal bone assemblages (18-40 per cent) than in the contemporary wheelhouses ( $6-16$ per cent) but the broch of Dun Vulan has greater proportions of front limbs than other body parts, suggesting that front leg joints of pork were brought to the broch from other communities (Mulville, in Parker Pearson \& Sharples 1999). The emphasis on pigs in the Dun Vulan assemblage is all the more striking given the virtual absence of woodland in the Outer Hebrides at that time - with woodland foraging unavailable, the pigs would have to have been fed on high-value foodstuffs so that their raising was itself an act of conspicuous consumption. In southeast Britain in the Late Iron Age, there are increasing proportions of pig bones (20-50 per cent) in certain settlements such as Skeleton Green (Ashdown \& Evans 1981), emulating the Gaulish élite and probably associated with the acculturated 'gallicized' élites in Britain (King 1991, 16). Special deposits of articulated or semi-articulated pig skeletons are found in pits within the western portions of settlements or within westfacing enclosures (Parker Pearson 1996, 127-8). Similar pig deposits are also common within the hillfort 
of Danebury (Wait 1985, 150) and are known from the hillforts of Balksbury (Maltby 1996, 23) and Winklebury, and the north-south oriented enclosure at Bishopstone (Wait 1985). Pig bones form a major proportion of the mammal bone assemblage from the hillfort of Croft Ambrey (Whitehouse \& Whitehouse 1974, 216). At the Middle Iron Age settlement of Groundwell Farm in Wessex, pig bones occur in similar numbers to sheep/goat (Coy, in Gingell 1982, 68); this settlement is anomalous because its enclosure entrance and house doorways face south and not east or west.

There has been a tendency to explain the varying quantities of pig remains on different sites as indicative of the availability of suitable woodland - for pannage (Maltby 1994, 9; 1996, 20-21), yet the Dun Vulan assemblage indicates that the rearing of pigs was socially rather than ecologically determined. Similarly, the presence of neo-natal pig skeletons within settlements has been taken as evidence that pigs were bred at these sites though these deposits may be interpreted as votive depositions rather than burial of farmyard casualties. In summary, the pig assemblages from settlements suggest a series of associations with élite residences, enclosures with westfacing entrances, and the western parts of settlements. Similar status associations for the pig can be found both in funerary depositions and in iconographic depictions. Pig bones are found as accompaniments to Iron Age burials in certain parts of Britain. In the presumed territory of the Durotriges in southern Britain during the Late Iron Age, pig bones are found only in inhumations where the corpse's head lies to the west whereas cattle and sheep are found only in eastward-orientated graves (Whimster 1981, 57). The iconographic contexts of boars, though presumably wild, also serve to highlight totemic differences between these and other animals. Motifs of boars are restricted to weaponry and war-gear (such as the carnyx or war trumpet; Fig. 5) whereas cattle are represented largely on cauldrons and firedogs, a distinction also found in continental Europe (Green 1992). ${ }^{3}$ The pig, contrary to its treatment in JudaeoChristian ideology as a dirty and polluting animal, appears to have had a very different status within British and Gaulish Iron Age society. Apart from the $\mathrm{dog} /$ wolf, it was the only domesticate which had an exact parallel surviving as a dangerous wild animal in western Europe at that time, and thus its place within both realms may have given it a very special status, which was enhanced by its culinary potential as a prime meat-bearing animal. Its position of superiority to catțle and sheep/goats in the hierarchy of
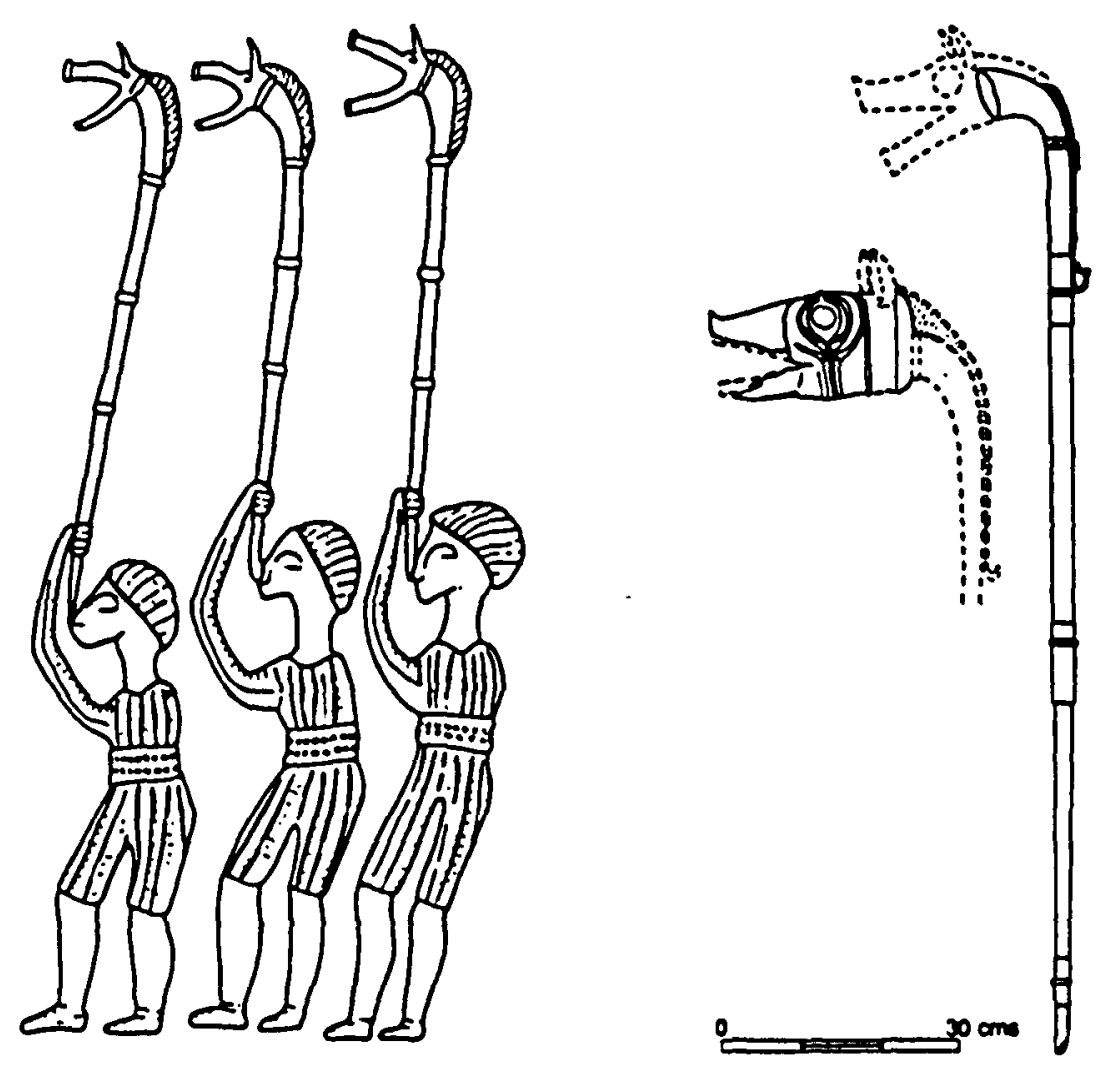

Figure 5. The boar symbolism of the carnyx (war trumpet) as represented on the Gundestrup cauldron and the two examples from Britain. (From Cunliffe 1995, drawn by Alison Wilkins, with permission from the author and Batsford.)

totemic associations for domestic animals mirrors similar distinctions between high-status and ordinary settlements, and between élites and commoners.

\section{Sunwise paths and the ordering of daily life}

The axial symmetry of roundhouses has been recognized for some time from the organization of their wall timbers and roof supports (Guilbert 1982; Reid 1989). It is further manifested in the Outer Hebridean wheelhouses (stone-built roundhouses with roofs supported on a series of radial stone piers, forming bays around the outer part of the house) by the design of the horseshoe-shaped fireplace and by the placing of special deposits of animal bones and/ or pottery in the area opposite the doorway (Campbell 1991; Parker Pearson \& Sharples 1999). The organization of activities within Iron Age houses can be reconstructed from a number of fortuitous cases from different parts of Britain. The best evidence comes from the Outer Hebridean wheelhouses of Scotland, the floors of which were sunk into the surrounding sand and thus were wholly preserved. Even though many of these were excavated over 40 years ago, their excavators were not oblivious to the patterning on floors and interpreted the differential 


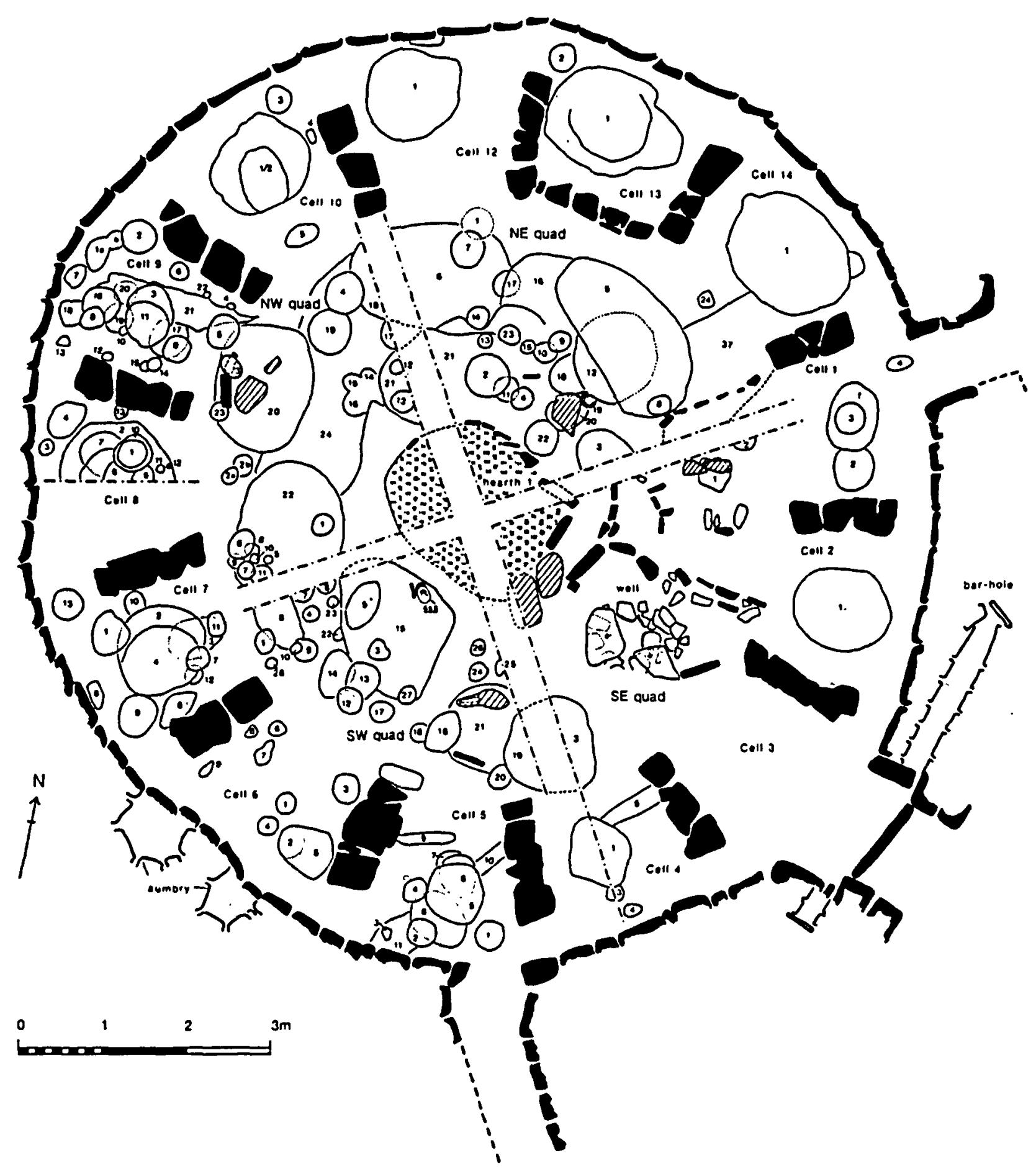

Figure 6. The plan of the interior of the Sollas wheelhouse. (From Campbell 1991 with permission from the author and the Society of Antiquaries of Scotland.)

floors. In contrast, the right side of the house is cleaner, there are fewer tools, and the bays are more likely to be demarcated by stone kerbs. Within the Sollas wheelhouse (Campbell 1991), these northern bays have large, shallow hollows suggestive of sleeping places, features which are absent on the south side (Fig. 6). The northern half of the east-facing house has a stone-flagged floor in certain brochs (for example, Hedges 1987; Ballin Smith 1994). This drier area is most likely to have been used mainly for storage and for sleeping.

In certain cases, wellpreserved Early Iron Age house remains in southern England allow similar analysis of interior organization. Fitzpatrick's spatial analysis of artefacts in the post settings of a roundhouse at Dunston Park, Thatcham, illustrates a south-north division of activities similar to that found in the Hebridean wheelhouses (1994). Very similar patterns can be identified in roundhouses at Long-

distribution of peat ash, pottery fragments, animal bones, quern stones, bone tools and even variations in sherd size in terms of differential use of space within the wheelhouse (Young \& Richardson 1960, 140-41; Fairhurst 1971, 79-80). More recent assessment of these results has established that activities were split between the two halves of the house, to the left and right sides of the east-facing door (Campbell 1991; Parker Pearson \& Sharples 1999). The left side of the house is characterized by artefacts and deposits relating to corn grinding, weaving, potting, ceramic storage and cooking debris. This zone may be further typified by the presence of small niches within the walls and by simple earth bridge Deverill Cow Down (Hawkes 1994) and Bancroft, Milton Keynes (Williams \& Zeepvat 1994). One of the houses at Longbridge Deverill (House II: $3)$, had burnt down and its floor survived intact. The deposits seem to have built up during the house's occupation rather than being specially placed prior to destruction. The majority of the pottery was concentrated in the southeastern and southern sides of the roundhouse, as well as in postholes of the structural timbers, especially around the southeast entranceway. Spindle whorls, bone gouges and chalk 'loomweights' (more probably 'firebricks'; Poole, in Cunliffe 1996) were clustered in the southwest/west side of the house. The northern side of the house, by 
a

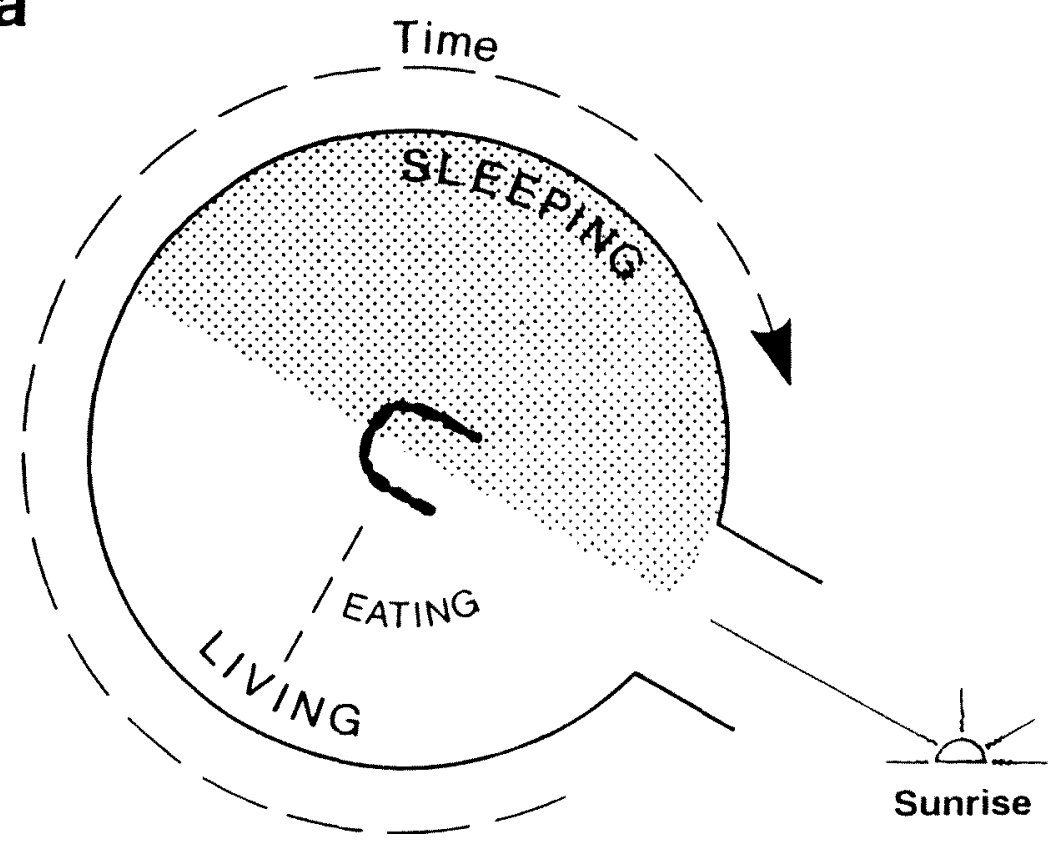

C

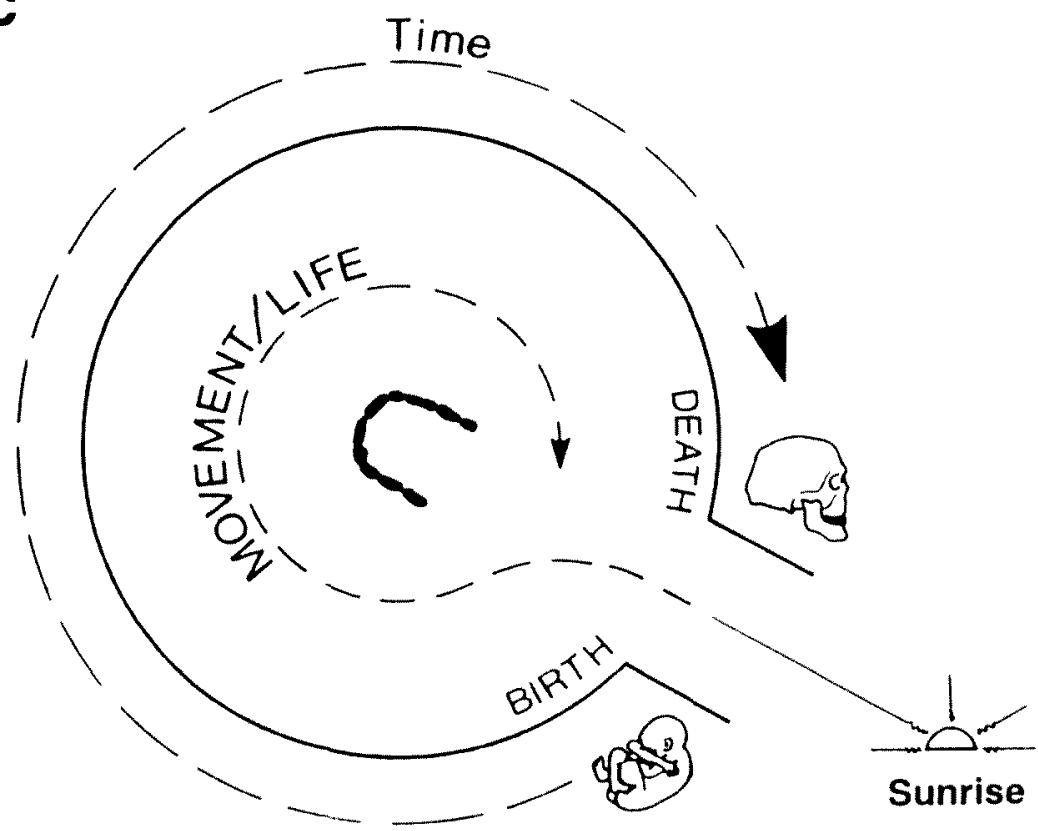

b

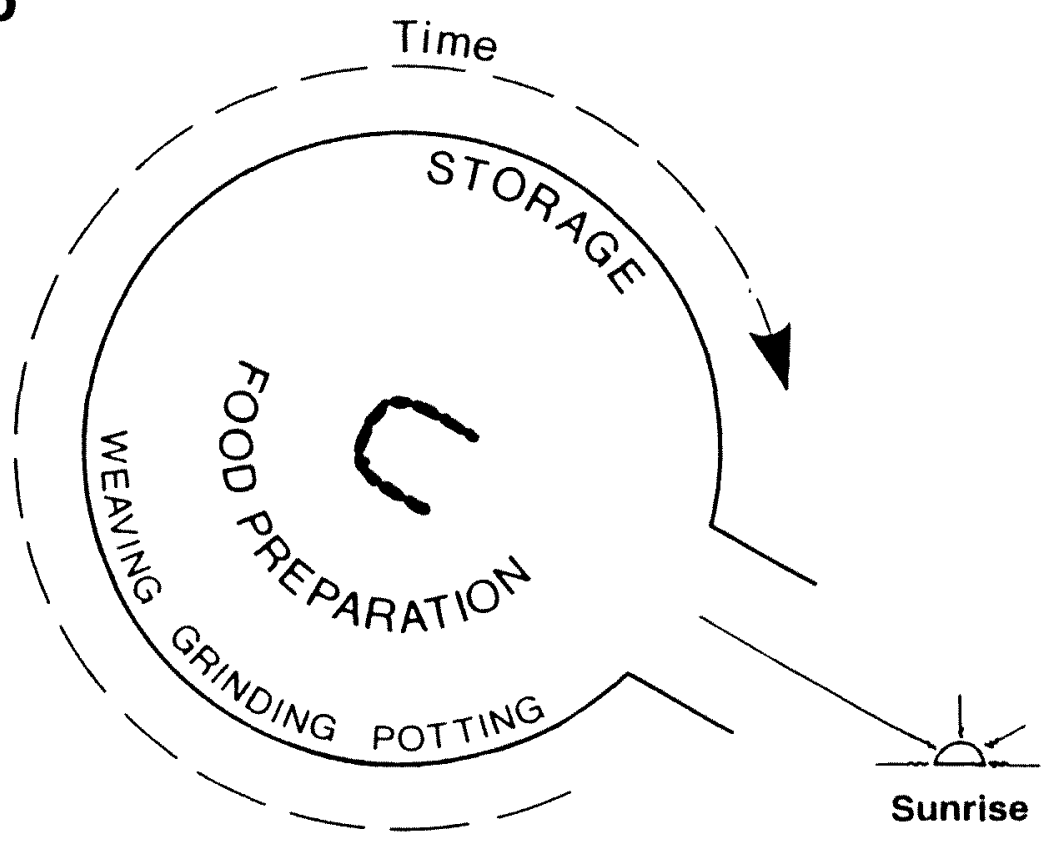

d

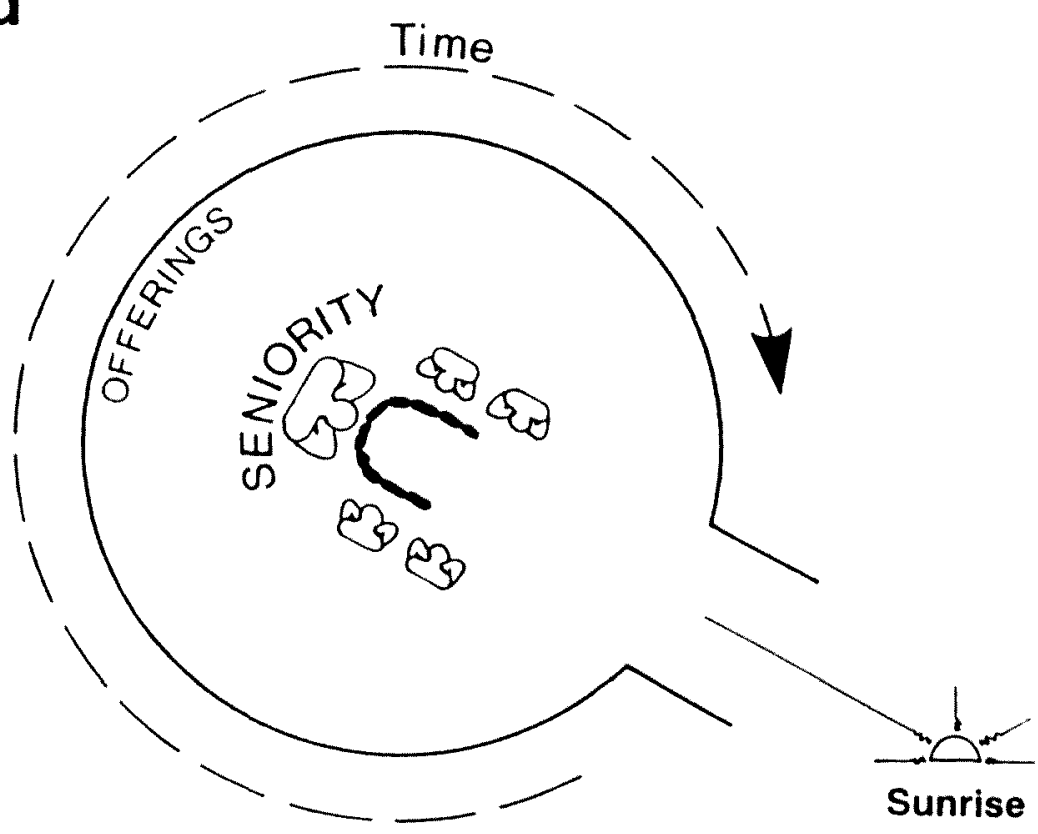

Figure 7. Interpretations of the use of space in British Iron Age roundhouses: (a) Fitzpatrick's sunwise scheme (Fitzpatrick 1994); (b) an extension of Fitzpatrick's scheme in the light of wheelhouse layout; (c) the sunwise pattern of movement within the house, including the metaphor of the human life cycle round the house; (d) the organization of seniority around the central hearth. (From Parker Pearson $\mathcal{E}$ Sharples 1999, drawn by Adrian Chadwick with permission from Sheffield Academic Press.)

contrast, is almost devoid of finds, except for one cluster of ceramics at the northern edge, pressed up against the back of the wall.

As noted above, roundhouse doorway orientations were dictated more by symbolic concerns than matters of wind direction, maximal sunlight penetration and comfort (Oswald 1997; Parker Pearson 1996; Parker Pearson \& Richards 1994a, 47-54). The location of doors, facing primarily towards the di- rections of sunrise at the equinoxes and the midwinter solstice, indicates that the passage of the sun was an important organizing principle in Iron Age daily and annual routines. Fitzpatrick has made the important observation that the division of diurnal activities within the roundhouse mimics the movement of the sun, with the tasks of the daytime carried out in the south and the activities of night-time in the north (1994): food preparation in the southern half 


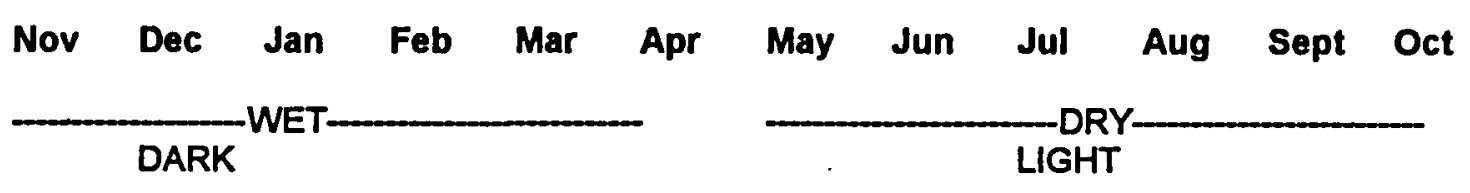

ETHNO-HISTORICALLY INFERRED

Crop cleaning, parching Com grinding, ploughing, sowing

Collect seaweed Spread seaweed, dung and midden on fields

Peat cutting, drying, stacking

Salt fish

Fresh fish, drying, smoking, storing in stacks

Animals in the in-fields and settlement

Animals graze the pastures

ARCHAEOLOGICALLY INFERRED

Culling

Culling

Fresh meat Dry and salt meat

Fresh meat Dry and salt meat

Make pottery Fire pottery

Carding Spinning Weaving

Dig clay Drying clay

Shearing Cleaning and drying

\section{FOLK CUSTOMS}

\begin{tabular}{|c|c|c|c|}
\hline Samain & Imbolc & Beltane & Lughnasa \\
\hline $\begin{array}{l}\text { Spirits of the dead } \\
\text { Fire festival } \\
\text { Year begins } \\
\text { Contact with Otherworld }\end{array}$ & $\begin{array}{l}\text { Fertility } \\
\text { Childbirth } \\
\text { Ewes lactating } \\
\text { dBaking } \\
\text { Purifying the house }\end{array}$ & $\begin{array}{l}\text { Fire and purification } \\
\text { Sex and fertility } \\
\text { Rekindle the hearth } \\
\text { Sunwise fire dance } \\
\text { Green man }\end{array}$ & $\begin{array}{l}\text { Stock rearing and harvest } \\
\text { Feasts, gatherings, races } \\
\text { Marriage of Lug and the earth } \\
\text { Sunwise fire dance } \\
\text { Loaves }\end{array}$ \\
\hline
\end{tabular}

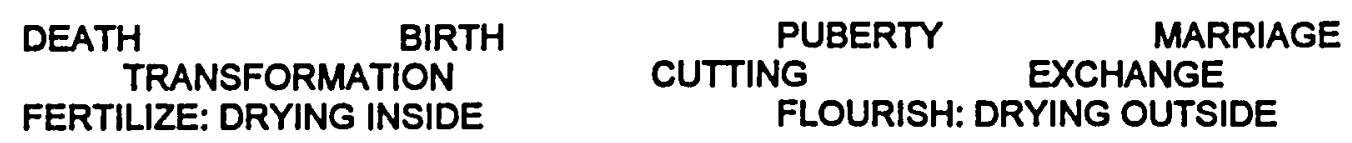

Figure 8. A reconstruction of the annual cycle of Hebridean Iron Age agricultural and domestic activities. (From Parker Pearson \& Sharples 1999 with permission from Sheffield Academic Press.)

by day and sleeping in the northern half by night (Fig. 7). There is a further clue to the organization of movement within the house from the organization of features within the wheelhouses of $A^{\prime}$ Cheardach Bheag and Sollas (Fairhurst 1971; Campbell 1991). In both cases, after entry through the door, stone kerbs guide access to the left, passing sunwise around the fire. Fitzpatrick's notion of time as sunwise progression is also complemented by sunwise movement. This sunwise movement is also built into the architecture of the brochs, in which the intra-mural stairs always ascend on a sunwise path. Even where roundhouses had doors to the west (Scott 1948; Young
Harvest Drying Stacking

Culling

1953), the sunwise principle was adhered to; the internal activities were simply rotated with the entrance so that the food preparation area was on the north side and the sleeping area on the south side. ${ }^{4}$

The principal axis of the house may have articulated the expression of household seniority within the house, with the head of the household's place at the fireside positioned so as to look across the fireplace and directly towards the door (Parker Pearson \& Sharples 1999). Alternatively, this axis served to divide those seated around the central fireplace into north and south groups. The floor of the well-excavated Sollas wheelhouse, however, revealed sitting hollows extending uniformly around the west, south and north sides of the hearth with no apparent division by the central east-west axis. A third alternative interpretation is that seniority was arranged around the hearth in a sunwise progression, with the youngest on the left inside the door and the oldest on the right. This model might dovetail with the first in that those in mid-life rather than old age may have been household heads and thus have sat astride the principal axis. The notion of sunwise passage embedded in the routines, of daily life within the house was probably employed at broader temporal and spatial scales. ${ }^{5}$ Some of the hillforts, enclosures and open settlements in southern Britain, such as Danebury (Cunliffe 1996), Winnall Down (Fasham 1985) and Easton Lane (Fasham et al. 1989), may have been organized as macrocosmic versions of the house interior (Giles \& Parker Pearson in press). The same is possible for the broader landscape, as hinted at in the accounts of land boundaries described in sunwise 
progression in the land charters and tribal hideages of the post-Roman period, along with other documentary sources (Dodgshon 1985). On the temporal scale, the organization of the agricultural year, commencing in November with food preparation, weaving, grinding and potting, and continuing through to drying and storage after the summer harvest (Figs. 8 \& 9), may similarly have mirrored the routines of the diurnal cycle (Parker Pearson \& Sharples 1999; Giles \& Parker Pearson in press). As mentioned above, the passage of a -human life may also have been tracked sunwise around the house from birth to old age and death (Fig. 7). Thus the doorway was the liminal space not only between inside and out but also between life and death on its two sides. The liminality of doorways and of entranceways may explain the use of enclosure entrances for furnaces and deposits associated with metalworking. It is notable that hillfort and non-hillfort enclosures like Gussage All Saints (Wainwright 1979), Maiden Castle (Sharples 1991, 100) and Collfryn (Britnell 1989) have metalworking residues within the enclosure entranceway, whilst the deposition of currency bars is similarly focused on entrances and enclosure boundaries (Hingley 1990b; 1997; Parker Pearson et al. in press; Giles \& Parker Pearson in press).

The fascinating Iron Age settlements and cemeteries of East Yorkshire tell us much about the living and the dead. The organization of daily life in the Iron Age of East Yorkshire probably conformed to the broad themes demonstrated above for other parts of Britain. The house plans from the Garton and Wetwang settlements conform in shape and orientation to those from elsewhere yet the absence of preserved house floor surfaces permits us only to surmise that they followed the sunwise path within its various spatial and temporal scales as described above. Despite the paucity of settlement evidence, the region is of crucial importance for the reconstruction of Iron Age cosmology. Its archaeologically visible funerary practices, under-represented throughout the rest of Britain, provide a specific regional perspective on orientational and animal symbolism within the funerary domain of a specific group of communities.

\section{Dividing the living from the dead}

The burial record for the British Iron Age is very fragmentary and many regions have few remains. East Yorkshire is one area where bodies were not burned or exposed but were buried in a grave pit surrounded by a ditched enclosure. This particular style of burial, in a square-ditched earthen barrow, is almost exclusively restricted (within Britain) to East Yorkshire region (Brewster 1982; Dent 1982) and has been considered to represent a culture group, the Arras culture (Stead 1979). The small but distinct funerary features have shown up either as earthworks or, after destruction by ploughing, as cropmarks. In contrast to the circular form of the house, these enclosures are nearly all square, forming a categorically distinct architecture similar to the temples/ shrines of Britain and to the houses of continental Europe. Perhaps the abodes of the dead were metaphorically linked to sacred enclosures and to the domain of the others who lived across the sea.

The liminal placing of the dead within the landscape is embodied partly through their relationship with water. The majority of East Yorkshire Iron Age barrow cemeteries are placed close to seasonal water sources, either streams or sinkholes (Bevan 1999). Such locations imply a liminal placement on the interface between the life world and the watery 
underworld. This liminality is further expressed by the regular association of burial areas with boundary earthworks of Iron Age or Late Bronze Age date (Bevan 1999), as at Danes' Graves which lies at the intersection of numerous linear earthworks (Fig. 10). In the case of Wetwang Slack, the cemetery was squeezed against a linear ditch and droveway which bisected the valley fields along the line of a stream.

Further distinctions between the realms of the living and the dead appear to have been inscribed in the choice of species and selection of body parts of the animals which occasionally were buried with the human dead. Pigs and sheep, generally as single bones or small portions, often accompanied the buried remains of the dead. In Yorkshire, in contrast to Wessex, these offerings never included the remains of cattle, though cattle bones are frequently found in pits and features associated with houses. Of course, pig and sheep bones are also found in domestic contexts but their deliberate inclusion in burials is in stark contrast to the placed

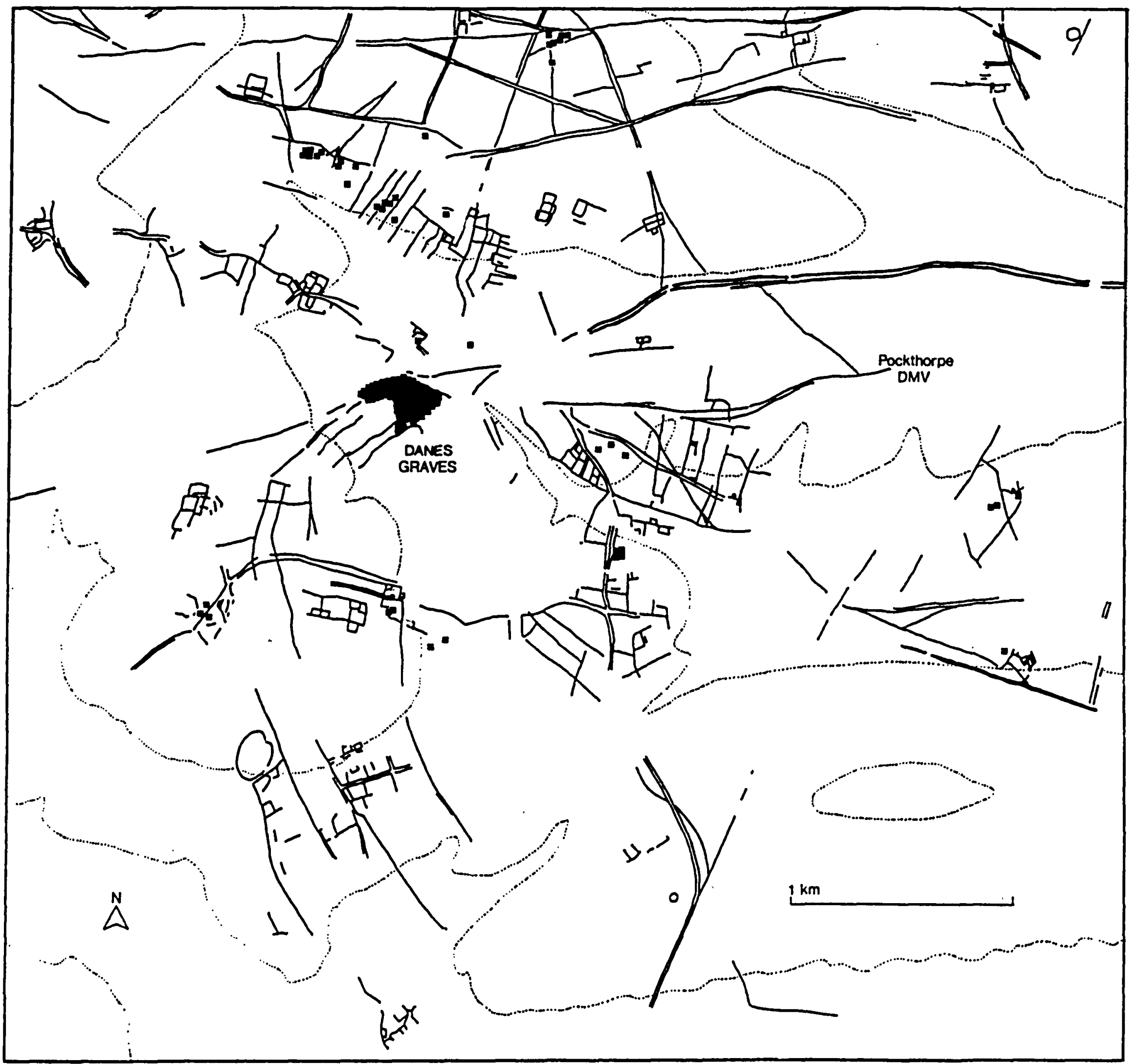

Figure 10. The location of the Danes' Graves Iron Age cemetery at the intersection of numerous linear earthworks. (From Dent 1982 with permission from the author and the Prehistoric Society.) 
deposits of cattle skulls and articulated body parts of cattle in settlement contexts. The only cases of cattle bones in burials are two complete animals, in humanstyle graves but without human corpses, at Garton Slack; this suggests treatment as metaphorical humans and not as funerary accompaniments. The portrayal of cattle in British Iron Age art (Green 1992) ${ }^{6}$ is a further corroboration of their symbolic association with the domestic setting; images of cattle are found on firedogs, key elements of the central hearth. In contrast, wild boar (the other frequently depicted animal) occur as motifs on swords, spears, 'standards', carnyxes (war trumpets) and armour.

There is another possible dimension of segregation between living and dead. ${ }^{7}$ It would seem that the rear (of both sheep and pigs) was reserved for the living. Pig bones placed in graves are always frontal parts (head, ribs and front legs), perhaps portions of pork. Sheep bones selected for inclusion with the dead are almost invariably left humeri. ${ }^{8}$ The preference for the left side of sheep may coincide with the preference for laying the corpse on its left side. Burials lying on their left sides are four times as prevalent as burials on their right sides. It is difficult to be certain but we might speculate that the lefthand side was considered inauspicious and perhaps associated with death. The large number of rightsided burials, however, gives cause for caution.

\section{Cosmology and body position}

The dominant burial rite in East Yorkshire involves the placement of the corpse in a crouched or contracted position on its left side, facing east with the head to the north and feet to the south. Other variations are rotations and/or reflections of this basic position, or east-west extended positions (which may be late in the sequence). Some of the northsouth crouched burials have grave goods, largely restricted to a brooch, a clay pot or a sheep's left humerus. The positioning of these modest grave goods sometimes marks gender distinctions (Fig. 11). Men were buried with a pot and/or a sheep humerus at their feet whilst in women's graves they were placed in the area of the head and hands. ${ }^{9}$ This English Heritage.) may portray a relationship between server/provider and served/provided, with women and some of the men represented as the providers of sustenance.

The types of grave goods accompanying eastwest and north-south graves are mutually exclusive. Whilst pots, brooches and sheep bones are absent, the east-west graves may contain swords, spears, knives, sickles, ornaments and tools, as well as pig bones. ${ }^{10}$ These graves are considered to be late in the sequence, perhaps dating to the first centuries $B C-A D$. Where the individual lies with his/her head at the east end of the grave, he/she is provided with the left side of the pig. When the head is at the west end of the grave, they are accompanied by the right side of pig (Fig. 12). I can find no key to unlock the meaning of this careful distinction. There is no correlation with sex, grave goods, age, body positioning or spatial location in the cemetery. It is a totemic indicator which could relate to lineage or moiety affiliations. It illustrates very clearly, however, that binary oppositions were in operation, combining orientational cosmology with left and right symbolism.

\section{Rethinking status: from grave goods to animal portions}

'The Iron Age chieftains of East Yorkshire and many of lower rank, to which the chariots obviously belong, were wealthy by the standards of their day and some must have had considerable political power.' (Brewster 1976, 110).
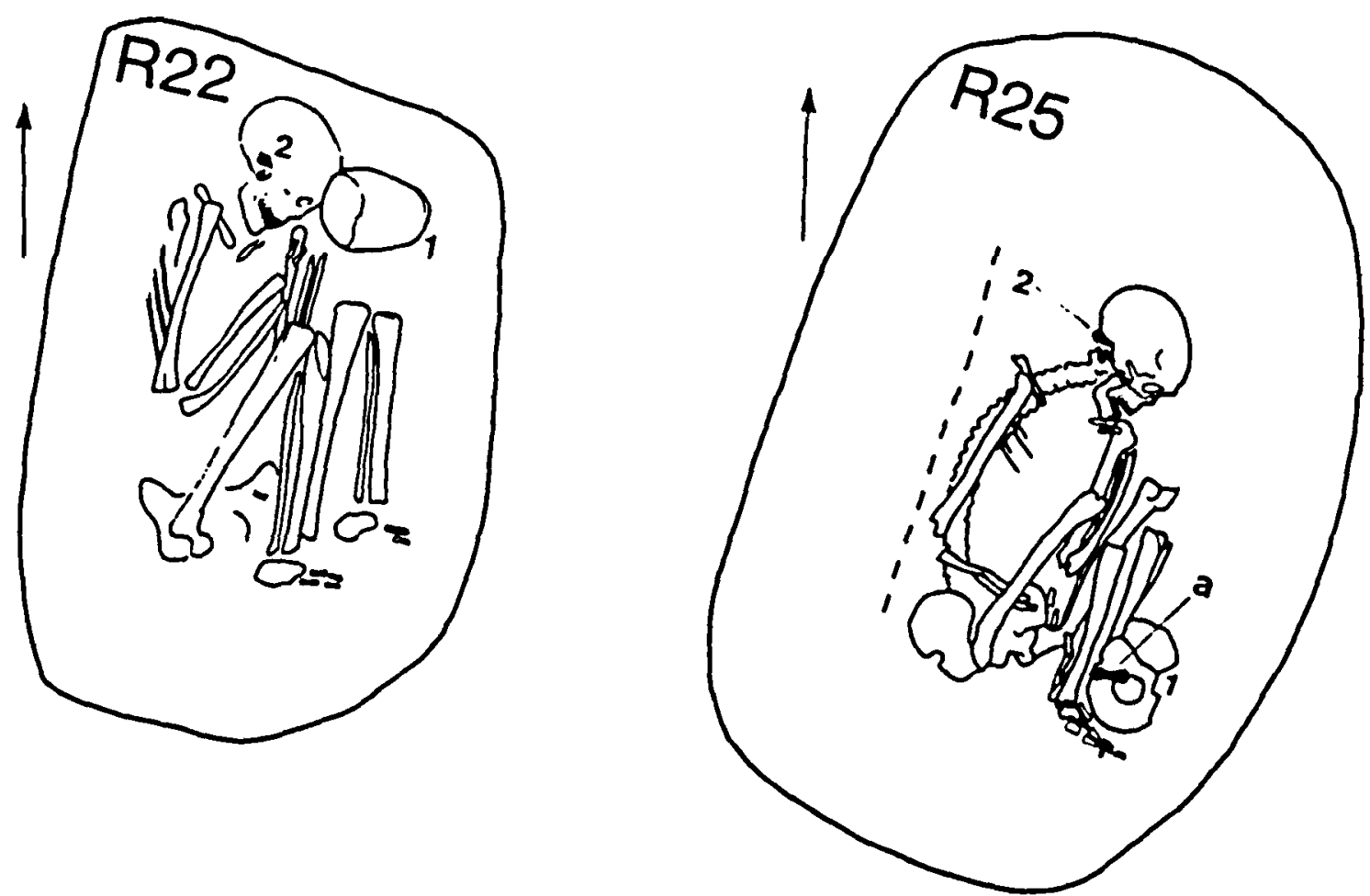

Figure 11. Gender distinctions in the placing of pots and/or sheep humeri within graves. (Adapted from Stead 1991 with permission from the author and 

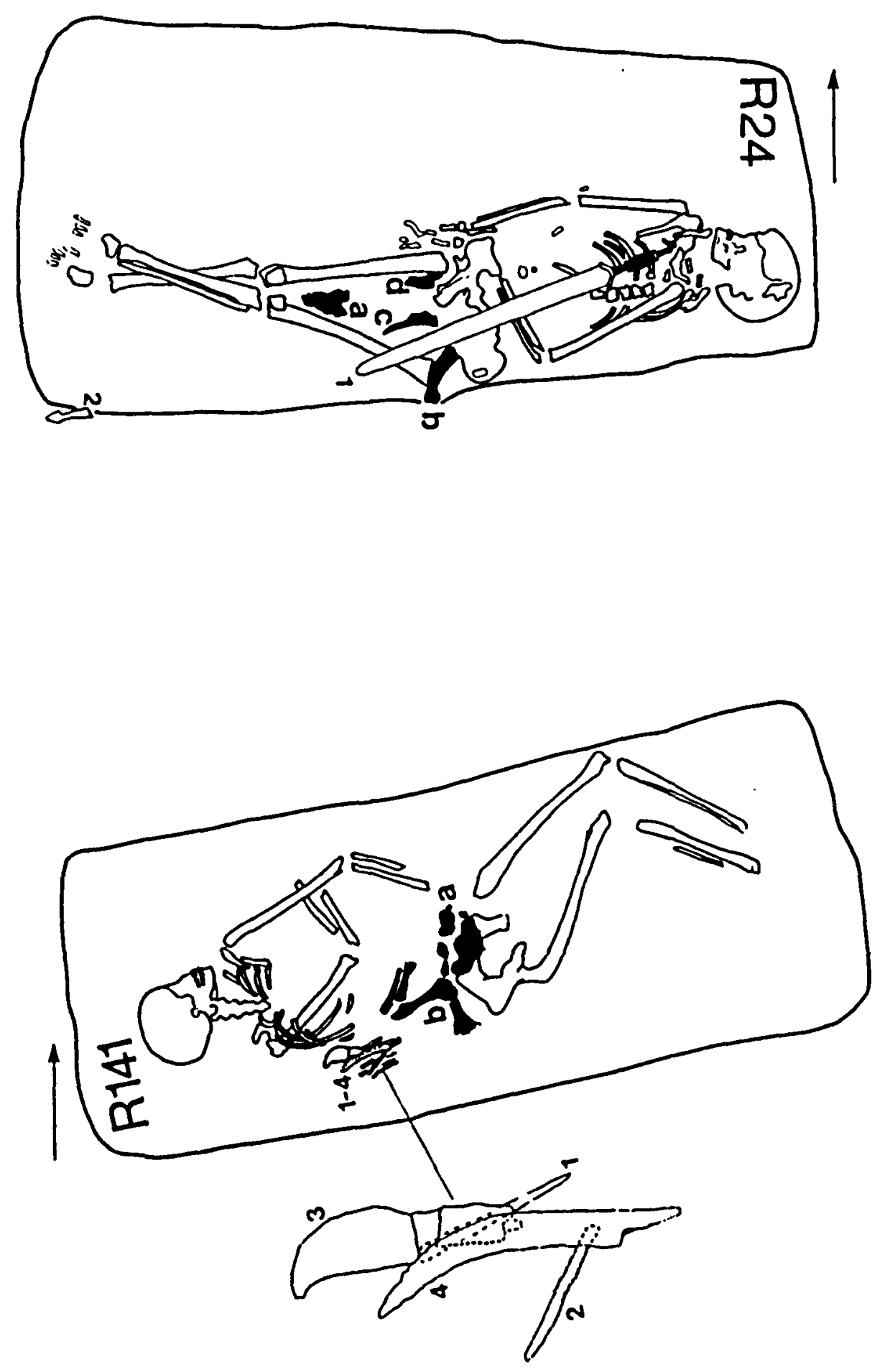

Figure 12. Possible moiety distinctions in the placing of left frontal pig bones in east-aligned graves and right frontal bones in west-aligned graves. (Adapted from Stead 1991 with permission from the author and English Heritage.)

Some time before New Archaeological interpretations of the social dimensions of mortuary behaviour had been adopted by British archaeologists (Chapman et al. 1981), the East Yorkshire burials were considered as evidence of a chiefdom, or at least a ranked society. The presence of carts (also described as chariots) has been taken to indicate the top level of this hierarchical order. Of the many hundreds of Iron Age burials from the region, no more than 14 were accompanied by carts. We must consider whether the cart is truly a mark of high indi-

vidual status or whether it might have had other meanings, perhaps associated with communality, pollution or social deviancy. It is possible that most burials involved the use of a cart, perhaps to convey the deceased to the grave, but that in most cases the cart was not deposited with the body. It might well have been so deposited, for example, because it had become tainted or polluted by a dangerous or unfortunate death. Alternatively, it may have acquired a 'sacred pollution' if it was associated with a good or auspicious death. As will become clear, the association of these burials with pig bones and with unusually fine items argues for their identification as graves of the élite.

The spatial organization of burials is divided into three: large cemeteries which are - often linear, small clusters and individual graves. Cart/chariot burials, probably dating from the third century $B C$, are found in all categories. Were carts, in any case, rare status items? Excavations of Iron Age settlements in other parts of Britain regularly uncover pieces of cart and harness fittings and they seem to have been relatively common features in British Iron Age communities though probably restricted to local élites (Cunliffe 1991, 492). ${ }^{11}$ Their inclusion in graves only in East Yorkshire highlights the rarity of this rite rather than the rarity of the carts, though their limited numbers point to a high-status association. In any case, their deposition may have been limited to a relatively short period within the Iron Age in the third century $B C$ on the basis of art style associations for five of them. ${ }^{12}$

Cart burials at Kirkburn and Garton Station (Fig. 13), in which the corpse is laid northsouth with the head facing east, are associated with bones of pig which are not only very specific parts of the animal but are placed in very specific positions around the corpse. They are always front parts - the skull and front legs and are split into left and right portions. The left portion is always placed on the north end of the body and the right portion on the south end. What we see in this placing of bodies and bones is a material construction of the cosmological grid in which left is equated with north and right with south. Conversely, the sole female chariot grave, where the positions are reversed, has right with north and left with south. This reversal may relate to the oppositional gender-signalling in the burials with 

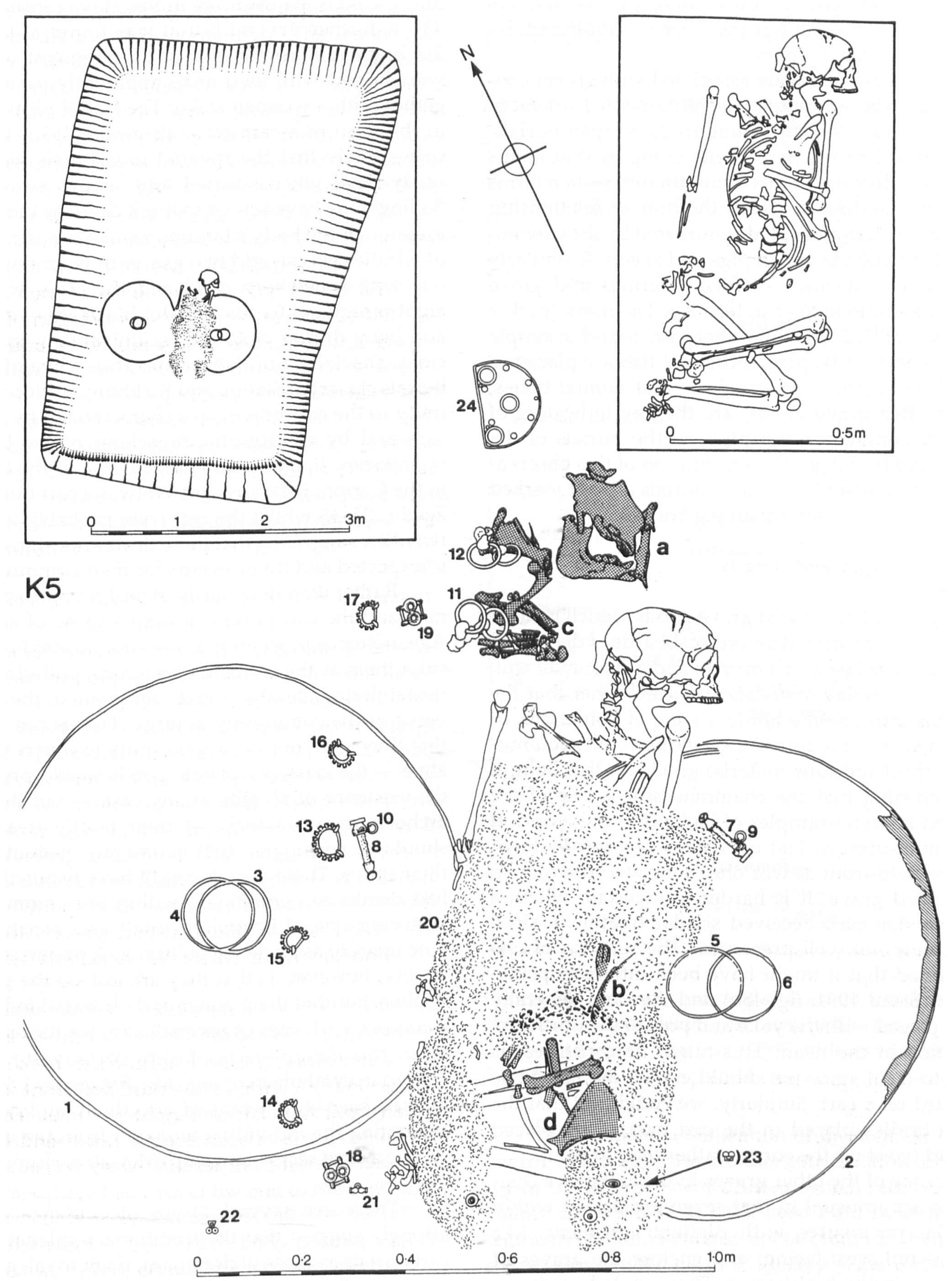

Figure 13. A cart burial with pig bones; the frontal left portion is by the head (north) and the frontal right portion is by the abdomen (south). (Adapted from Stead 1991 with permission from the author and English Heritage.) 
sheep humeri and/or pots. More cart burials are known at Wetwang but there are no published details of the animal bones.

Since pig bones are associated with graves containing carts, weaponry and ornamented artefacts, whilst sheep bones are found in the simpler burials, we appear to have two species being used as status markers. ${ }^{13}$ In structuralist terms, this opposition forms a totemic system in which the human relationship between rulers and ruled is mirrored by the ceremonial distinction between pigs and sheep. A similarly totemic classification of food offerings and grave goods is found in Roman Iron Age Denmark (Parker Pearson 1993, 221), where sheep are found in simple burials and cattle, pigs, birds and fish are placed in lavish ones. We may conclude that animal bones, rather than grave goods, are the key indicators of élite or commoner ascription in the burials of the Yorkshire Iron Age. The implication of this observation is that many high-status burials are not marked by grave goods, other than pig bones.

\section{Carts, deviancy and royalty}

The carts and associated grave goods, which include elaborately decorated sword scabbards, a decorated bronze container and a mirror, and a chainmail suit, are not everyday items and indicate either that the persons thus commemorated were of noble rank or that their death required the sacrifice of the community's most precious material goods. In this light, it is interesting that the chainmail suit is one of the earliest known examples of its kind in the world. It was, interestingly, laid over the body upside-down and back-to-front as was one of the swords from an associated grave. It is harder to ascertain whether the wooden carts received similar treatment, since they were not well preserved. The remains of one suggested that it might have been interred upsidedown (Stead 1991, fig. 48b) and the carts generally were placed with the yoke and pole to the north, the direction of the head. This might be construed as back-to-front since we should expect the feet to be forward on a cart. Similarly, we could add that the horse bridles placed in the cart burials are placed behind (west of) the corpse rather than in front.

Some of the other graves in the cart grave cemeteries are unusual in that seven are placed within circular enclosures with distinct entrances, like houses but west-facing, and enclose the graves of males or individual horses. These male burials are especially unusual because they include multiple spearheads (up to 14 in one grave) which were thrust into the body whilst it lay in the grave (Stead 1991, 33). A further deviant burial was found at Garton Slack where a young man and a pregnant woman were buried with their arms apparently pinned together with a wooden stake. The burial pit was cut in the form of a cart grave (Brewster 1976, 115). It seems likely that the speared individuals were already dead when speared and so this secondary 'killing' may have served to mark death as the transgression of the body's boundaries. To this catalogue of oddities we can add two graves of young women, one with a newborn child and the other with an eight-month old foetus. The double death of mother and baby during childbirth is universally inauspicious, shocking and dangerous. Thus some of these burials at Garton Station and Kirkburn, in close proximity to the cart graves, are characterized by inversion and by catastrophic breaching of the body's boundaries. It is also notable that one of the bodies in the Garton, Kirkburn and Wetwang cart burials is aged c. 35-45 whilst the rest were probably in their twenties, suggesting that these deaths may have been unexpected and tragic events for their communities.

Rather than necessarily identifying the speared men and the cart graves as simply those of an Iron Age aristocracy, we might be better advised to consider them as the result of dangerous, polluting and destabilizing deaths which threatened the wellbeing of the community at large. That is not to say that they were not of superior rank to others whilst alive - the existence of élite goods would presume the existence of an élite in any case - but that the archaeological evidence of their bodily treatment should be considered first before any evaluation of their status. These burials might have resulted from bad deaths of commoners within the community, requiring special inversion rituals and sacrifices of élite items to assuage the pollution. A preferred possibility, however, is that they are indeed the graves of élites but that the manner of their burial indicates a concern with rites of reversal and, for the speared men, the metaphorical killing of royalty. This Frazerian symbolism of regicide (Frazer 1911, 9-119) may be seen as a means of effectively and rapidly separating the individual monarch from the eternal and immortal sacred kingship (Metcalf \& Huntington 1991, 162-88).

There are several pieces of evidence which strongly suggest that the traditional explanation of cart burials as those of dominant, if not royal, groups is correct. First, some of the artefacts in these graves are scarce and unusual, such as the chainmail coat in Grave 5 at Kirkburn. It might have belonged to the 
man in the grave or might equally have been a special item discarded by a mourner. The female cart burial at Garton Slack was provided with similarly rare and elaborate artefacts, namely a mirror and a bronze canister. Other special artefacts in cart burials are swords with ornamented metal scabbards. Another indication of royal status is that west-facing square enclosures are found in association with these burials at Garton Station. As noted above, this reversed orientation can be considered to have been associated with difference and high status.

We must conclude that the cart burials are.highstatus burials but they are often associated with inauspicious, even dangerous and polluting graves. Cart burials seem to have occurred early in the sequence (c. $300-200 \mathrm{BC}$ ) and may have been used later as foci for 'bad deaths', perhaps to contain their pollution by association with the graves of senior ancestors. Of course, as representatives of a sacred kingship, their own deaths would also have been considered especially inauspicious, dangerous and even polluting.

\section{Cemetery groupings, kinship and body treatment}

The spatial organization of the large linear cemeteries of East Yorkshire can be studied in some detail. Many of the larger cemeteries are linear and some can be seen to be formed of clusters of graves (Figs. $14 \& 15)$. From dating of brooches, the north-south linear cemetery at Rudston appears to conform to this pattern, having grown from a series of points along its length and not developed progressively in one direction or another. This suggests a series of clusters which, over time, have spilled over into each other. Whilst male and female graves are evenly distributed along the length of this cemetery, there is a greater frequency of female graves towards the west.

There are indications that these clusters formed discrete social groupings. Burials with pig bones at the Rudston and Burton Fleming cemeteries are in clusters separated from those with sheep bones. Certain clusters are distinguished from others by their tomb architecture, characterized by small conjoining semi-detached grave ditches, in contrast to the freestanding square barrows of the rest of the cemetery. A further form of clustering is revealed by the differential treatment of the corpse. Body position can be classified as flexed, crouched or contracted (tightly crouched as if bound). The contracted burials are not randomly distributed in the cemetery but are very common in some parts and absent in others.

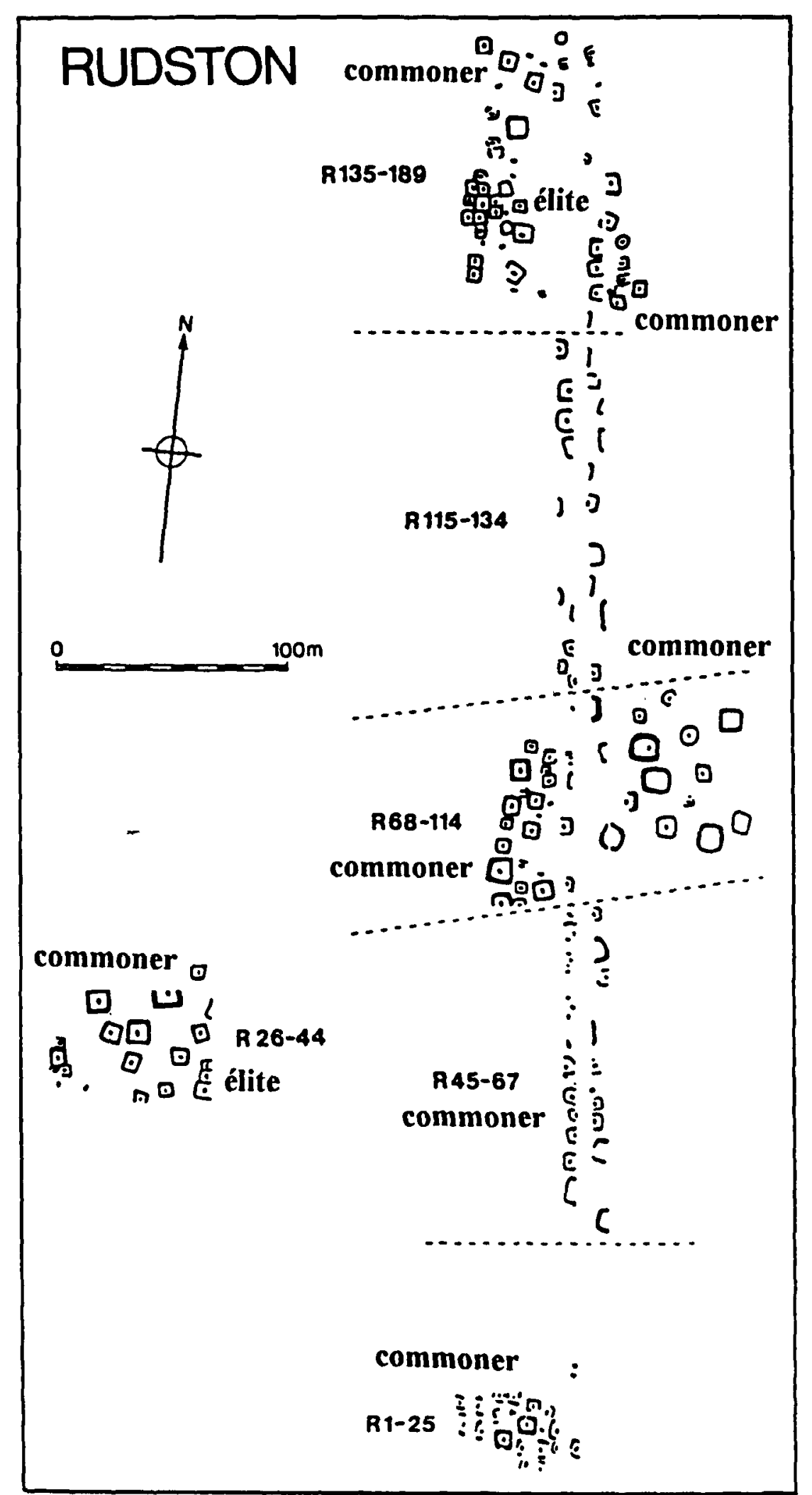

Figure 14. The linear cemetery at Rudston, divided into élite (marked by conjoining barrows) and commoner lineages. (Adapted from Stead 1991 with permission from the author and English Heritage.)

The compartmentalization of these linear cemeteries finds an echo in the construction of the region's Iron Age linear ditches, which recent excavations have found to have been built in different -segments (Julian Henderson pers. comm.). The cemeteries form spatial maps of kinship organization in which each cluster is a lineage of either élite or commoners (though many of the Early Iron Age élite lineage clusters are located away from the commoners' 


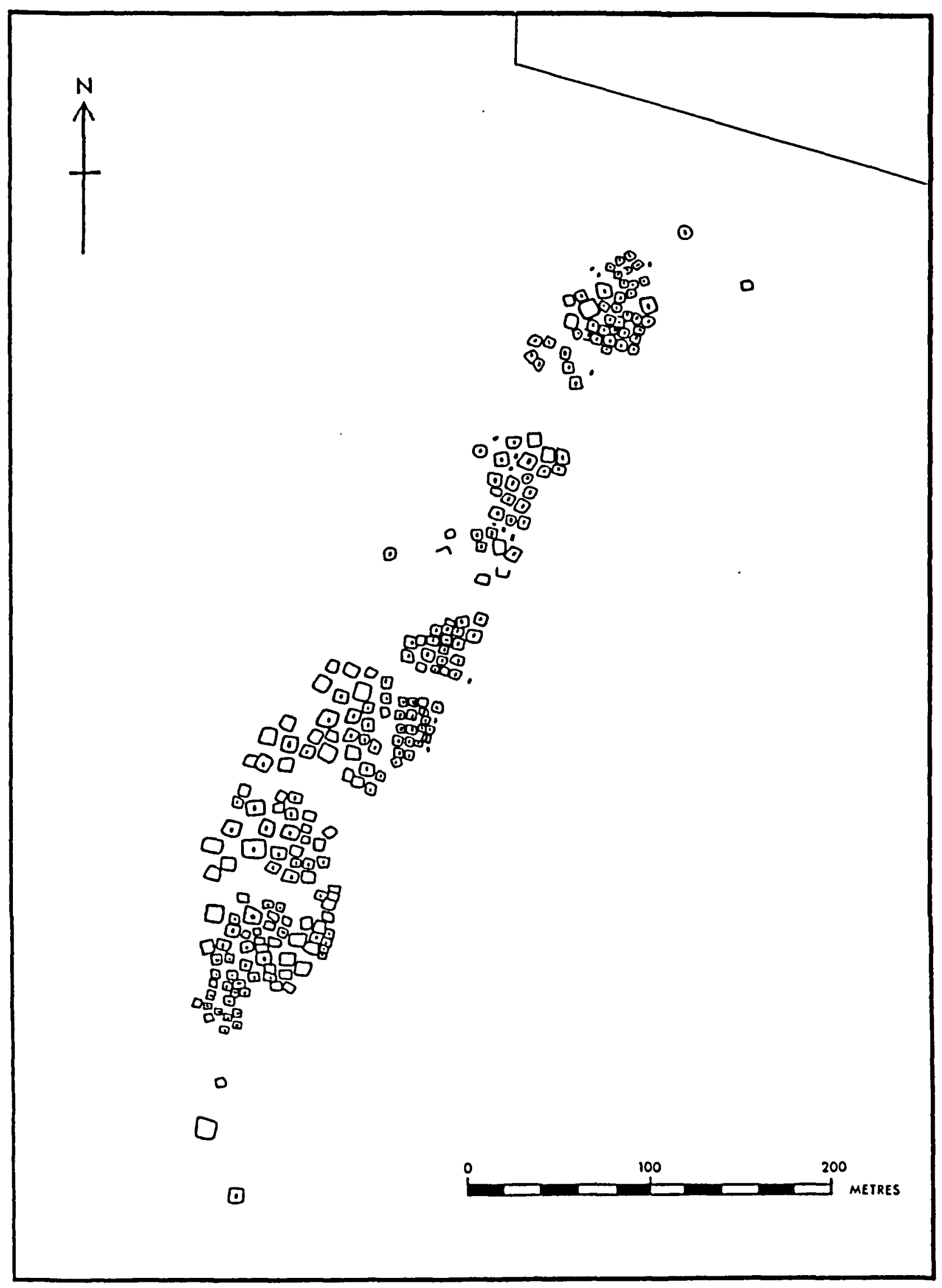

Figure 15. The linear cemetery at Carnaby, composed of discrete clusters. (From Whimster 1981 with permission from the author and British Archaeological Reports.) cemeteries (S. Stead, in Stead 1991). It is also worth noting that the traits are twice as commonly shared between adjacent males as females. It appears that male kin are buried together in the same cluster. In contrast, women would seem not to be buried with those to whom they are genetically related. This suggests that a virilocal pattern of burial was in operation, with most of the women in each cluster having originated in other communities. This, in turn, suggests a patrilineal descent system. We should exercise caution, however, in interpreting such nonmetric traits as necessarily genetically heritable; the spatial clusterings are perhaps best considered separately from the non-metric data.

\section{Conclusion}

Death is a moment when our attitudes to the body are presented most clearly and prominently, often in ways which are very different to body treatment in everyday life. The body of the corpse becomes the focus of ritual and mourning. Mourners also adopt poses, positions and styles of movement which may be highly formalized and controlled, or alternatively frenzied and stricken. The corpse may be manipulated, orientated, sat up, laid down, dressed, undressed, washed, provided with gifts and even fed. It may be consumed, burnt, buried, excarnated, held down with stones, dug up, displayed, hidden, placed under the house floors of the living or taken as far away as possible. In most societies, if not all, the corpse is an embodiment of the pollution, spiritual 
and material, which threatens to engulf the mourners and which must be mediated, controlled and overcome.

The human body is perhaps the ultimate natural symbol, providing a basis for simple concepts such as up/down, back/ front, left/right, in/out, and clean/dirty. The treatment of an inert corpse provides a setting where such symbolism is mobilized on the body of the dead, on the bodies of the mourners and even on the bodies of animals which may be slaughtered or sacrificed in the rites.

Remains of the dead are an important form of evidence for archaeologists investigating ancient attitudes to the body. Not only do we find how the corpse was eventually left to rest but we may also find traces of how the mourners acted in provisioning the corpse and in laying it to rest. Social relationships between and among the living are given representation in the way that the corpse is treated. Differences between women and men, children and adults, living and dead, and between kin groups, status groups and other totemic groupings may all be manifested in the wide variety of ways in which the body of the dead is treated. The use of animal bodies may also be significant in the same vein. Different species or sexes of animals, or different parts of their bodies, may have significant totemic

Figure 16. Two lineage groups at Burton Fleming, defined by their cores of orthodox graves $(3-6,8$ \& $11-13,16-18)$ and their fringe of unorthodox burials. $\Gamma \mathrm{N} / \mathrm{S}$ facing $E ;$ LS/N facing $E ;\rceil N / S$ facing W; \rfloor $S / N$ facing $W$. (Adapted from Stead 1991 with permission from the author and English Heritage.)

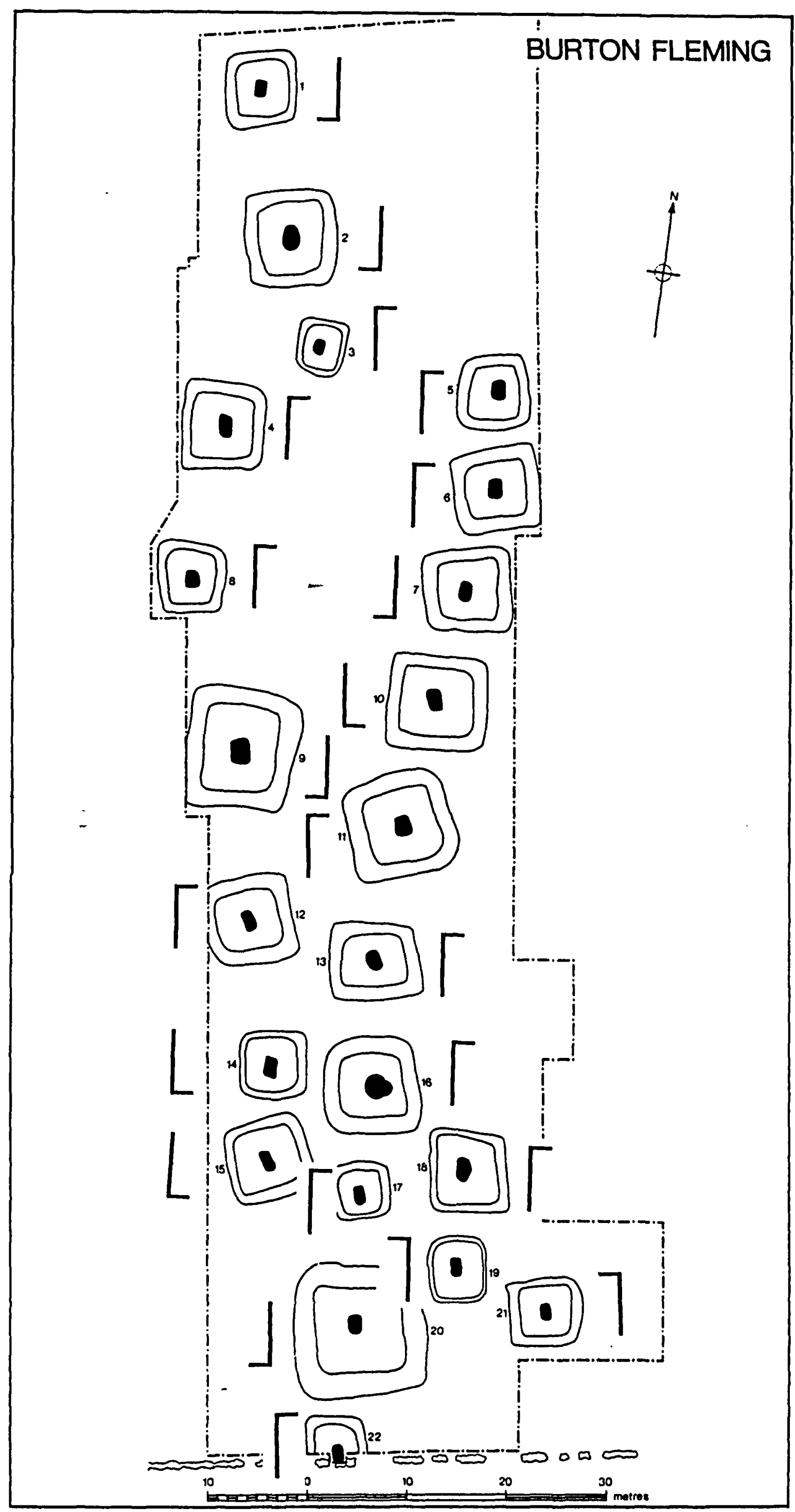


symbolism. The different parts of an animal consumed at a funerary feast may represent different social relationships and statuses among the mourners. The funeral is a moment when individuals must repair the torn fabric of community and engage in the political struggle to re-create society.

The treatment of the body tells us much about social relationships in the British Iron Age. The practice of square barrow burial, restricted to East Yorkshire, hints at a strong regional and group identity. The ways that the body is laid in the grave are linked to lineage affiliation, class membership and cosmology. The positioning of grave goods may define gender and possibly moiety. Placing of animal body portions is particularly rich in symbolism, with pig and sheep bones embodying a totemic status distinction between élite and commoners.

I have identified two main status groups on the basis of body treatment, rather than simply by grave goods or barrow construction. These are:

a) burials with pig portions and those which include the Early Iron Age cart burials, the Late Iron Age extended east-west graves, the childbirth deaths and the speared men;

b) north-south burials, occasionally with sheep bones (these define the dominant rite and are commoners);

In addition we can also recognize another category which is under-represented in the burial record:

c) children under about 16 years of age, presumably excluded because they were not considered fully sexual or socialized members of society. It is also likely that the entire adult population of Iron Age Yorkshire is not represented by these square barrow burials and that this is only a proportion, albeit sizeable, of the total population.

Although studies of social structure based on grave goods provision and energy expenditure have been criticized for some time, there have been very few analyses which have explored body treatment and developed a more contextual and sophisticated approach to investigating social relationships (although see Pader 1982 for an early example). This article has attempted to explore some of the potential by linking treatment of the body with orientational cosmology, animal symbolism, and spatial patterning in settlement and cemetery as well as in grave goods provision. Not only are aspects of Iron Age cosmology recoverable from cross-contextual archaeological approaches which deal largely or entirely with prehistoric material, but also certain prehistoric cosmologies appear to have been widespread and long-lasting. For example, the organizing principles of the east-west axis and the sunwise path were adopted across Britain from southeast England to northwest Scotland in the centuries after c. $900 \mathrm{BC}$ and were to remain, with certain regional modifications and expressions, until the first millennium AD. Rather than being ephemeral 'ways of thinking' subject to continuous and active change, these cosmologies were durable and long-lasting, embedded in the traditional architecture and practices of daily life over many generations. In conclusion; this study has implications for the ways that archaeologists understand the British Iron Age and other prehistoric societies in terms of the relationship between structure (the traditions through which society is constituted) and the transformative nature of agency. I have focused on structure because it is only through the prior identification of cosmological rules that we may proceed to understand human agency in relation to those rules. Secondly, the emphasis on human agency in recent accounts of British prehistory (e.g. Barrett 1994) often draws extensively on theories of structuration (e.g. Giddens 1984) in which agency is given ontological value greater than that of structure. Not only was Giddens' theorization explicitly designed for industrial and post-industrial societies whose workings he considers to constitute a radical break from all previous societies, but archaeologists have also applied those formulations to past societies without heeding 'Giddens' own misgivings about any universalizing social theory which stands outside time and history. We need to consider more carefully the implications of distinguishing between traditional societies, in which the ways of the ancestors are revered and provide an unquestionable basis for action, and technologically advanced societies in which innovation and fashion are treasured. The archaeological record of prehistoric Britain, and perhaps prehistory in general, would seem to indicate that cosmological traditions could be powerful and enduring. At the same time, they were subject to local understandings and resistances. Yet what is important is that the various manifestations are indicative of a common understanding which was both long-lasting and geographically extensive within Britain.

\section{Acknowledgements}

The excavations by T.C.M. Brewster, Ian Stead and John Dent have contributed substantially to our knowledge of East Yorkshire's Iron Age settlements and cemeteries. In addition to their published and unpublished work, a number of unpublished papers 
(as doctoral, masters, and undergraduate dissertations) have been produced by students at the University of Sheffield, and I am very grateful to Bill Bevan, Ross Dean, John Dent, Ian Marsden, Angela Piccini and Alice Pyper. This paper has benefited from discussions of related papers at the Delhi WAC, Reading TAG, the Hunter Archaeological Society and seminars at the archaeology departments of Sheffield University, Reading University and the University of Wales, Cardiff. Thanks to Richard Bradley, John Dent, Andrew Fitzpatrick, Mel Giles, Richard Hingley, Simon James, Jacqui Mulville, Niall Sharples, Ian Stead and the two anonymous reviewers for their useful comments.

\section{-Notes}

1. It is intriguing that this grid of associations is found linguistically in Irish and Scots Gaelic, possible successors to pre-Roman languages in the British Isles. The word for 'east' also means 'front'; 'west' is equated with 'behind', 'left' with 'north' and 'right' with 'south' (Robinson 1986, 135). Of course, we have no means of establishing for certain whether a language similar to Gaelic was spoken in Iron Age Britain.

2. Its orientation, like that of Mucking South Ring, is not towards the midwinter sunrise but slightly north of this direction.

3. Towards the end of the Iron Age both bull and boar motifs occur on Continental-derived coinage of Roman extraction. It should be noted, however, that the bull motif on British coins is sufficiently abstract so as not to be recognizable as an animal at all and we must doubt whether it was perceived as such.

4. It is interesting that sunwise movement is encapsulated in the Gaelic word deasil - 'motion towards the right, in the apparent direction of the motion of the sun'. Its linguistic opposite, 'withershins' - traditionally considered the wrong way, unlucky and illfated - is of Icelandic and/or Germanic derivation.

5. We have no appropriate written sources for Britain but there is an intriguing but ambiguous reference to the Continent:

The stoic philosopher Posidonius ... says: ... When a large number dine together they sit around in a circle with the most influential man in the centre... Beside him sits the host and next on either side the others in order of distinction. Their shieldsmen stand behind them while their spearmen are seated in a circle on the opposite side and feast in common like their lords ... They use a common cup, drinking a little at a time, taking no more than a mouthful, but they do it rather frequently. The slave serves the cup to the right, (not) to the left. That is the method of service. In the same way they do reverence to the gods, turning towards the right. (Athenaeus 4, 36, translated by Tierney 1960).

As Simon James points out (pers. comm.), if the slave is in the middle and serving to his right, as seems most likely, then the cup passes sunwise. Turning towards the right for the gods seems less ambiguous as a sunwise motion if one starts from facing east.

6. We can also include western European Iron Age art, in which cattle occur in addition on cauldrons.

7. Since the haunches (hip, buttock and rear legs of the animal) are presented in Celtic mythology as the champion's portion (Ross 1967, 403; Green 1992, 170-71), the frontal part represents a lesser status.

8. From Ian Stead's excavations at Burton Fleming and Rudston, just three out of 37 sheep humeri were rightsided.

9. From Burton Fleming and Rudston, eight biologically female individuals have pots/bones near their heads and three have them by their feet; of the biologically male individuals, four have pots/bones near their feet, two near their heads and one by his waist.

10. Animal bones are found in only 16 per cent of eastwest graves but they are always of pig.

11. By the Late Iron Age they were probably fairly common; Caesar's reference to Cassivelaunus and his 4000 charioteers may be exaggerated but points to their likely availability among local communities.

12. The three Wetwang carts and the Garton Station and Kirkburn burials are third century $\mathrm{BC}$ but the others are undated.

13. By ornamented artefacts I refer to the use of Celtic art motifs on items such as the 'bean-can'.

Mike Parker Pearson
Department of Archaeology E Prehistory
University of Sheffield
Sheffield
S102TN

Comments

From Miranda Aldhouse Green, SCARAB

Research Centre, University of Wales College, Newport, Caerleon Campus, Newport, NP6 1 YG.

Mike Parker Pearson presents a fascinating and essentially persuasive argument for the presence of linkages between life, death and cosmology in the British Iron Age, nodal points being the symbolism of the human body and the respective orientations of houses and graves in relation to the sun's diurnal path. Additionally, it is argued that social differentiation may be embedded in certain recognized patterns of ritual behaviour, including the deliberate selection of specific body-parts of particular animals for deposition within both living accommodation and graves.

In general, this article reflects its author's usual combination of meticulous academic rigour and challenging interpretation. But a few somewhat dogmatic 
statements concerning meaning strike a discordant note. For instance, I take issue with the unequivocal claims for the interpretation of house-orientations as expressive of cosmology. This may well be right but, in dealing with material culture alone, it is wise not to be too uni-directional in the identification of symbolism: the application of theoretical perspectives to archaeological evidence is important in developing prisms through which to view the past, but they are theoretical approaches and should not become 'factoids'. Neither should we dismiss the possible relevance of custom and practice to the organization of living-space. To take a modern analogy, the 'normal' British house has a front living-room and a front-facing main bedroom but there is no functional reason for this; neither is it ritual in any sense other than convention.

Notwithstanding the cautionary note sounded above, this is an exciting article which raises a number of important and wide-ranging issues, thus making a valuable contribution to our discourse with the material culture of the British Iron Age. A particular interest, for me, lies in the discussion of possible liminal symbolism associated, for instance, with the selection of pork as depositional material because of the existence of both the domestic pig and its wild counterpart. Indeed, one could point to the omnivorous habits of pigs as further support for their perception as liminal creatures. Interestingly, some Late Iron Age and Gallo-Roman iconography also suggests a link between pigs/boars and boundary-symbolism: one example is the ambiguously-gendered sow/boar figurine from Cahors; another is the human/boar image from Euffigneix.

Several other issues addressed by Parker Pearson resonate with broadly coeval iconography: reversal in handedness can be discerned in some female images on Iron Age coins and Britanno-Roman sculpture; the under-representation of youth in Iron Age Yorkshire graves reflects special, if negative, treatment of people yet to attain sexual maturity; in the substantive assemblage of pilgrim-imagery at the Gallo-Roman sanctuary of Fontes Sequanae, near Dijon, children between nine and fourteen years old (both girls and boys) are depicted idiosyncratically, wearing 'badges' of youth and carrying pet animals, as if they were perceived as different from the rest of the pilgrim population. The possibility of identifying symbolic linkages between ritual behaviour in the Iron Age and cult-imagery of Iron Age and Roman date is to me one of the research areas of cognitive archaeology which could profitably be explored in future work.
From Barry Cunliffe, Institute of Archaeology, 36 Beaumont Street, Oxford, OX1 2PG.

This is an enjoyable and stimulating article which introduces a welcome new approach to Iron Age burial data moving us away from purely chronological/artefact orientated studies. The author convincingly demonstrates that patterns of behaviour exist and that those patterns may be susceptible to interpretation. Rather than concentrate on detail I would like to comment on method. Where our data sets are large enough it is possible to recognize patterns of behaviour and, in considering these patterns, we may discern structures conditioned by belief. Attempting to understand these beliefs is one of the legitimate goals of archaeology. Given a data set the first stage in the process is pattern recognition. Most of us, I suspect, would prefer to stand back from the detail to spot recurring themes and then to focus on them. This is an entirely legitimate procedure which relies on the human mind rather than mechanical computer-led techniques. But there are dangers in this. By cherry-picking we run the risk of writing off all non-cherries as background noise, i.e. houses that do not face our preferred southeast direction are anomalies. Strong congenial patterns may obscure weaker 'unwanted' patterns. In this way sought-for patterns gain a legitimacy and importance which they may never have had. In the background noise and anomalies may lie something much more interesting. In other words we must seek consciously to put our preferred patterns into context the better to understand them.

Many Iron Age houses do indeed favour a southeast orientiation but many do not. Could it be that other factors, including simple topography, may be dominant and only by default (when those factors are not operative) were houses aligned in the direction of the welcoming early morning sun? Similarly, hillforts in south-central Britain do tend to an east-west orientation but to what extent is this a factor of the natural grain of the geology? More interesting are those where entrances do not conform rationally to topography.

What I am arguing is that pattern-recognition is indeed a valuable first step, but it must be followed by rigorous testing against the totality of the data, lest the patterns which we find obvious and interesting obscure others that may have been more significant to the communities we are trying to understand. 
From Richard Hingley, Historic Scotland, Longmore House, Edinburgh, EH9 1SH.

Parker Pearson's article is an indication of how far Iron Age archaeology in Britain has come over the past 20 years. It is now possible to build credible interpretations of gender, group identity, status and time on the basis of the archaeological evidence. I find the author's approach stimulating and exciting. His defence of structure against agency runs counter to the dominant perspective in late twentieth-century prehistoric archaeology, but it does express a concern that is held by a number of his colleagues. Parker Pearson also shows his structuralist leanings in his focus on binary oppositions (east-west, north-south, -élite-commoners, women-men, living-dead, etc.).

The use of settlement and burial evidence from a large area of Britain enables the author to build some complexity into his account, yet the rather simple cosmological interpretation that he develops also causes a measure of concern. He suggests some variation in the way in which cosmology was defined across Britain, variation which is reflected in varying archaeological evidence, yet the clockwise cosmology based on east (life) and west (death) is felt to be fundamental across Britain for the first millennium BC. I accept that the cosmological idea is a useful tool, but I also feel that later prehistoric life must have been more complex than this interpretation would suggest.

Whose version of cosmology does this replicate? That of the household head or the most junior member? That of the women or the men? I would suspect that different groups within society may well have held varying views of the significance of their world; some subtly different and some radically so. Lévi-Strauss $(1968,132-41)$ in his work on the Winnebago, suggested that members of two distinct descent groups had markedly different views of the social relevance of the same village plan, and I have explored an alternative interpretation of the spatial significance of circular architecture during later prehistory elsewhere (Hingley 1990a). Perhaps some of these variations in the way that people viewed the same material reality during later prehistory partly explain the changes to the archaeological evidence that occur through time.

In my rather more complex interpretation of Iron Age cosmology there would certainly be no difficulty with the idea of having distinct later prehistoric interpretations of clockwise east-focused cosmology in different areas of Britain. In a previous article Parker Pearson suggested that west-facing roundhouses in Wessex could be connected in some way with death (Parker Pearson 1996), while in the article in this volume he suggests that in the Western Isles west-facing houses might relate to high status. He further suggests that the Atlantic Scottish evidence can be used to inform his earlier view about Wessex and that, perhaps, a variety of west-facing houses throughout Britain all relate to high status. I would prefer a view of cosmology which allows for a more subtle, contextually-defined interpretation. Using this approach, there is, for instance, no difficulty with the idea that the Atlantic Scottish examples exhibited some form of power relations between people while the Wessex examples were related in some way to concepts of life and death. In any case, these two sets of values may in some way be connected.

Material for these variable interpretations may not be difficult to find; for instance, what is the relevance of the rectangular buildings which occur in southeastern England during later prehistory (Hingley 1989, 35)? Does the cyclical model work in these cases, or is a Danish-style cosmology (as represented by the presumably cosmological movement of the 'Chariot of the Sun': Jensen 1993, 54) more relevant to later prehistoric societies who live in rectangular houses?

These comments do not detract from the value of the work on which Parker Pearson's article is based. We might perhaps, as he has suggested, see this basic cyclical cosmological framework as a key to unlock the symbolism and practice of daily life and seek to build more complex accounts which deal with variability across Britain. We also need to consider change through time using the key of cosmology. It is also important that we consider the relationship of ancient cosmology in this part of Europe to that of neighbouring areas of the Continent, if we are to understand the evidence in more subtle terms.

From John Dent, Scottish Borders Council, Planning \& Development, Council Headquarters, Newton St Boswells, Melrose, TD6 0SA.

Parker Pearson explores a number of different aspects of life and death in this article. Having long puzzled over such matters as burial positions and roundhouse orientations, I extend a cautious wel- come to these ideas for the extra dimensions which they provide to over-familiar material.

I have been invited to comment on this article, largely because of my interest in the Iron Age settle- 
ments and burials of the Yorkshire Wolds where three sites are of particular importance to Parker Pearson's case. These are Garton Station/Kirkburn, Garton/Wetwang, both in the central Wolds to the west of Driffield, and Rudston/Burton Fleming in the northeastern Wolds.

Garton Station and Kirkburn constitute a single site which consists of a nucleated cemetery and outlying barrows at a place where in exceptionally wet seasons a spring rises and forms one of the headwaters for the River Hull. These headwaters also attracted ritual activity in the Neolithic, Roman, and Anglian periods. Ditched Iron Age enclosures with western entrances, and a consistent rite involving speared inhumations are features which distinguish this from other cemetery sites.

Garton/Wetwang lies to the west of this site, in a dry valley, or slack, which emanates from the main massif of the Yorkshire Wolds. Long-term gravel extraction along more than 1.5 kilometres of the valley floor led to the excavation of an extensive Iron Age settlement of 80 or so round houses, and more than 450 burials, which included four with carts or chariots. An extensive linear ditch system several kilometres in length followed the dry valley from the springs at Garton Station/Kirkburn to well beyond Garton/Wetwang, and in several places was a focus for burials.

Rudston/Burton Fleming is a large assemblage of Iron Age burials from the gravels of the Great Wold Valley and its tributary, Bell Slack. This valley system leads to the North Sea at Bridlington Bay.

In his discussion of 'West orientation and social difference', Parker Pearson refers to the large settlement of Garton/Wetwang. This settlement extended along the valley floor for at least 1.5 kilometres (some may have been lost without record to gravel quarrying at the eastern end). The position of a 'village street' is indicated by the position of some roundhouses and post squares, by isolated square barrows, and by later linear features. It is quite clear that, unlike medieval and later villages, there was no attempt to build roundhouses to face the 'street', even where they were ranged along its sides. The doorways in almost every case occupied the southeast quarter. A single example in which the door faced southwest is identified here as a probable highstatus building, seemingly because of nearby post squares (putative granaries). In fact, there are twice as many 'granaries' at the west end of the settlement, where the roundhouses all conform to the usual orientation. On the other hand, a closer look at his roundhouse reveals that it is unusual in other ways.
Roundhouse is a reasonable interpretation of this structure, for the penannular slot $11.5 \mathrm{~m}$ in diameter falls within the range of other structures in the valley. Unusual is the southwestern entrance and its width of $4 \mathrm{~m}$, as well as the lack of internal post holes (although many, admittedly smaller, roundhouses lacked internal supports). Much of the interior was occupied by a large pit up to $7 \mathrm{~m}$ in diameter, funnel-shaped and with its bottom resting on chalk at a depth of $3.5 \mathrm{~m}$. Human bone was recovered from the lowest fill of this pit. Outside the entrance was a second large pit, about $5 \mathrm{~m}$ diameter and $1.5 \mathrm{~m}$ deep. In the bottom of this 'ritual hollow' (the excavator's interpretation) a central mound of gravel had been left unexcavated. These features need not have been contemporary but their juxtaposition on the extensive valley floor is too convenient to be accidental, and suggests that whether roofed or not, the circular structure was rather special, as Parker Pearson suggests.

We are increasingly aware of the importance which various peoples placed on their homes and the significance of their use and treatment. Feng Shui was an ancient belief before it became a middle-class fad, and 'Sunwise paths and the ordering of daily life' suggests how Iron Age Britons may also have given careful consideration to the arrangement and use of their houses. Even though at Garton/Wetwang there is little to suggest how houses were used (since the floors of houses did not survive), the ideas put forward in this section are thought-provoking and need not be restricted to prehistoric contexts. Did such a clockwise tradition of movement, for example, influence the design of spiral staircases, which almost invariably turn to the right? The argument that this was to give defenders an advantage with their sword arm may be a retrospective view which would not have impressed early ecclesiastical architects.

'Dividing the living from the dead' draws on the abundant evidence from East Yorkshire where cemeteries are frequently placed against boundaries, and sometimes close to water. The builders of long barrows and round barrows in the Neolithic and early Bronze Age had a preference for ridgeways at, or close to crossing points, and valley floors where these too were on natural routeways. Many Iron Age cemeteries are also in places where they would be seen from trackways, and many trackways were also boundaries marked by linear earthworks. Such burials could be said to occupy liminal positions, but were not marginal in the sense of being 'remote'. Rather, many must have been prominent features of the landscape. 
Garton/Wetwang is actually several miles from the nearest water, whereas Garton Station/Kirkburn is part of an historic ritual landscape which may owe its very existence to the presence of springs. The majority of Late Iron Age settlements known from aerial photography (and represented by rectilinear enclosures) concentrate on the lower dip slope of the Wolds around the Hull Valley. The cemeteries in this area, particularly Arras, Garton/Wetwang and Garton Station/Kirkburn produced the richest grave goods of the whole burial tradition, with carts/chariots and fine metalwork.

This may reflect the greater ease of access to the Vale of York (for iron) and the continent (e.g. for coral and glass) which the Hull Valley enjoyed in - contrast to the relative isolation of the northeastern Wolds. Even though the Rudston/Burton Fleming area had been of exceptional ceremonial importance in earlier times, it was not accessible to small craft, unlike the River Hull, which is navigable almost to its source.

Parker Pearson's discussion of body treatment, grave goods and the significance of food provides a good deal for thought. It is worth mention here that Jean Dawes examined all the skeletal material from Garton/Wetwang, and observed that limb bones sometimes showed unequal development, with the arm bones of one side being more robust than those of the other. Attracted by the possibility that this contrast might enable us to identify right- and lefthanded individuals, we were disappointed to find that there was no correlation with which arm had been uppermost in the grave.

Although this article necessarily draws heavily on East Yorkshire for burial evidence, the excavations at Garton/Wetwang in particular have dispelled the myth that this evidence is somehow irrelevant to other areas. The use which Parker Pearson makes of the information may in some instances prove to be wide of the mark, but he is surely right to pursue these intriguing avenues of inquiry, and to relate the Yorkshire evidence to a wider group of people.

From Ian Ralston, Department of Archaeology, University of Edinburgh, 12 Infirmary Street, Edinburgh, EH1 1LT.

This is a mainline paper within the new - and rather diverse - paradigm (e.g. papers in Gwilt \& Haselgrove 1997) which is emerging in Iron Age studies in Britain, and to which Mike Parker Pearson has been a major contributor. It is a useful tour $d$ 'horizon of work already done, which is rather dis- persed in the literature (e.g. Parker Pearson 1996), and incorporates both new insights (e.g. from ongoing work in the outer Hebrides) and the application of strands of post-processualism to data sets already published (e.g. Stead 1991). A linking theme in the various components of the article is the wish to extract new meanings from the detection of pattern at a variety of scales in the archaeological record. Although some of the examples of decoding proffered seem more convincing than others, the approach clearly has value. Furthermore, after the ethnic schism marked by the unwillingness in certain archaeological circles to apply the term 'Celtic' to the Iron Age record from Britain (cf. Megaw \& Megaw 1997) the reappearance, at least for purposes of illustration, of Gaelic linguistic comparanda for certain of the practices noted here will be welcomed in some quarters.

A basic premise underpinning the work is the existence of a preferential east-west orientation in the structural record. This is certainly, as the author maintains, sustainable for some regions and categories of evidence. How generally it holds, however, remains to be more fully established: enclosed later prehistoric sites of the central Scottish Borders and the southern Hebrides, areas checked at random in compiling this note, both seem to be exceptions. The author considers.orientation and its associations at a variety of scales: within individual buildings, in terms of burial practice (including the selection of accompanying grave goods), and in relation to the entrance orientations of enclosures and the debris selectively incorporated in sectors of their ditches.

In some instances, the evidence in the casestudies seems over-emphatically proposed. Thus the apparent chronological primacy of the cart burials within the Yorkshire cemeteries would not be universally accepted, nor their attribution solely to the fourth century BC. Amongst other practices, northsouth burial here interestingly seems to precede eastwest, which only later became the dominant position (e.g. Stead 1991; James \& Rigby 1997). Parker Pearson nonetheless constructs an insightful and, in some aspects, compelling picture. To this writer's mind, however, the case for a widely-standardized (at least in its basic precepts) cosmological system across Iron Age Britain based ultimately on such regularities remains not proven, and, in fairness, Parker Pearson - concludes by making due allowance for local variability and indeed explicit resistance to a dominant tradition.

Both within Britain and beyond, other data sets and other perspectives may be marshalled both to 
sustain or to argue against components of Parker Pearson's hypotheses. The significance of pigs in the diet of the last centuries $\mathrm{BC}$, for example, is something recorded not simply on British sites (e.g. Meniel 1987): does a developing taste for salted or cured pork underpin in part the rise of this animal in osteoarchaeological terms? Elsewhere in Britain, new data may sustain elements of the case (for example, the excavations now under way of square barrows in eastern Scotland). It may equally provide challenges, as for instance on the basis of a wider regional reading of Atlantic Scottish evidence (e.g. Gilmour \& Cook 1998). At a number of points, Parker Pearson instances potential continental comparisons, and here too there is scope to pursue orientations and their implications (e.g. Almagro-Gorbea \& GranAymerich 1991). There is clearly more to be extracted from the juxtaposition of the nominally-ritual, -ideological and -domestic in revitalizing Iron Age studies.

\section{Reply by Mike Parker Pearson}

It is three years since I wrote this paper and, written today, it would read rather differently. Many cf the criticisms, drafted recently, are entirely fair and are received gratefully. In particular, they raise three aspects which merit further discussion. The first is whether architecture embodies cosmology as opposed to custom and practice. The second is whether the search for structure has any place within theories of agency. The third is the relationship between meaning and practice.

Material culture is not so much a text to be 'read' as a set of practices to be lived. Yet the extent to which people are knowledgeable about - and capable of reinterpreting or resisting - the oftenunacknowledged customs and traditions by which they live may vary considerably. When we talk of cosmology we perhaps perceive it as 'ungrounded theory', symbolic and esoteric knowledge about the world which has no practical application. I have tried to use it in a rather different sense akin to Bourdieu's conception of 'habitus' or Giddens' duality of agency and structure, as an understanding of the wider world which is grounded and realized through people's lived relationships especially within the house and its organization (Bourdieu 1977; Giddens 1984). In response to Miranda Green's criticism, cosmology is not ritual as opposed to custom and practice - not only is ritual an aspect of custom (Lewis 1980) but cosmology is the systemization of thought which is inherent in human action. To take her example of the contemporary British house, I have elsewhere summarized the work of Roderick Lawrence and Nigel Barley which argue for recognition of the unacknowledged cosmologies which inform the 'common sense' practices and customs of inhabiting our houses (Parker Pearson \& Richards 1994b, 6-9).

One of the main aims of this and an earlier paper (Parker Pearson 1996) was to demonstrate the limited applicability of our own cultural logic, practical reason or common sense for understanding how Iron Age people dwelt. This entailed the recognition that their concepts of pragmatic utility were different to ours. A good example of the significance of eastwards orientation over-riding 'pragmatic' concerns can be found in the Iron Age enclosure at Haddenham, Cambridgeshire, where the east-facing porch leads directly into the ditch of the enclosure; it must have made access out of the house hugely inconvenient but that was not the principal concern. Once.we can understand that such aspects of orientation and layout were so important in people's lives we can then begin to perceive patterns and anomalies, mentioned by Barry Cunliffe, as relating to people's perceptions and understandings rather than to a universal pragmatic or practical reason in which we simply import present concerns (with weather, lighting, view and topographic siting) into the past and thus learn nothing. The step which we have yet to take is to explore the human agency behind the diversions from custom as well as behind the continuance of custom; we can only do this, however, if we know what that set of customary practices structure - actually consisted of. In doing so, we can take Iron Age archaeology through a series of conceptual paradigms - from functionalism through structuralism to theories of agency - which has taken the other social sciences nearly half a century. I am not so much defending structure against agency, as Richard Hingley suggests, but attempting to explore the duality of structure and agency (Giddens' structuration) in which agency cannot exist in a vacuum but relates to custom and tradition. Firstly, we must be prepared to acknowledge that the interrelation of structure and agency may have been different in pre-modern 'traditional' societies. Secondly, without understanding those historically specific traditions, beliefs and customs, our theories of agency will either fail or will merely impose our own particular culture-bound pragmatism dressed up as phenomenological insight into Iron Age life. If we do not understand the over-riding significance of orientation, for example, we might be misled into thinking that the view from an Iron Age doorway was of prime significance, a construct rooted in our contem- 
porary framing of the landscape as aesthetic object.

I was particularly excited to read John Dent's description of the southwest-facing roundhouse at Wetwang Slack with its strange pits, human bones and wide entrance, emphasizing this house's specialness in relation to the others which face east and southeast. This brings me to the issues of meaning and local, situated understandings raised by Richard Hingley, Ian Ralston and Miranda Green. If the large pit with human bone, filling the house interior, was contemporary with the house walls, then we are not looking at a residence, let alone an élite one, despite the fact that evidence for such an élite can be clearly recognized in the funerary evidence. Rather, the associations may have been primarily with death or, as Hingley suggests, with both death and élite status. My own misgivings on re-reading my paper include this lack of full consideration for multiple meanings, whether successive and context-bound, perceived by different members within one community, or interpreted differently in different regions of Iron Age Britain. Agency-focused investigations must now explore the specific circumstances and contextual associations of each anomalous 'non-east-facing' roundhouse, as well as regional differences in deviation from the orthodox. At the same time our examination of agency should attempt to account for the traditions of house orientation and layout coming into existence around $900 \mathrm{BC}$, spreading throughout the British Isles but not on the continent (or does it?), enduring for over a millennium in parts of Britain, and eventually coming to an end around $A D$ 200-400 north of the Roman frontier. The geographical extent and longevity of roundhouse orientation and internal organization leads us to question the extent to which meaning is entirely individually contingent and not subject to common understandings. Some aspects of cultural practice are non-discursive and unacknowledged - the shaking of hands is a geographically and temporally extensive form of greeting but we do not often question whether it should be or why we do it. Other practices are clearly understood and recognized but are not contentious whereas related issues are - in Britain we drive on the left whereas elsewhere people drive on the right; this is not a practice causing confrontation and multiple understandings whereas the construction of more new roads is. To use Hingley's example, the Winnebago may have had different views of the village plan but they would have been in no doubt about how their houses were arranged internally according to custom. We have to acknowledge that there have been some remarkable continuities and common understandings which survived for long periods of prehistory despite the multiple meanings and continuous changes around them. This was not a solipsistic world in which each individual lived their own private culture; were that so then the British Iron Age would have been lived in houses of all shapes and sizes and internal arrangements. The remarkable point about certain practices is that they endure despite individual and local resistances and experimentations and despite the loss of former meanings, a point nicely made by John Dent in his reference to clockwise spiral staircases in churches and castles many centuries after roundhouses and brochs. Looking in the other direction, back towards earlier prehistory, it is also worth commenting on the peculiarly British phenomenon of circular architecture from $3000 \mathrm{BC}$ onwards which, transformed from ceremonial and funerary contexts into domestic forms, provided an enduring contrast to the rectangular architecture of continental Europe.

\section{References}

Almagro-Gorbea, M. \& J. Gran-Aymerich, 1991. El estanque monumental de Bibracte (Mont Beıvray, Borgoña). Madrid: Editorial Complutense.

Armit, I., 1996. The Archaeology of Skye and the Western Isles. Edinburgh: Edinburgh University Press.

Armit, I. \& A. Dunwell, 1992. Excavations at Cnip, sites 2 and 3, Lewis, 1989. Proceedings of the Society of Antiquaries of Scotland 122, 137-48.

Ashdown, R. \& C. Evans, 1981. Mammalian bones, in Skeleton Green: a Late Iron Age and Romano-British Site, by C. Partridge. London: Britannia Monograph Series, 235-41.

Ballin Smith, B., 1994. Howe: Four Millennia of Orkney Prehistory. (Monograph 9.) Edinburgh: Society of Antiquaries of Scotland.

Barrett, J.C., 1994. Fragments from Antiquity: an Archaeology of Social Life in Britain, 2900-1200 BC. Oxford: Blackwell.

Bevan, W., 1999. The dead can dance: the landscape context of square barrow cemeteries in the East Yorkshire Iron Age, in The Loved Body's Corruption: Archaeological Contributions to the Study of Human Mortality, eds J. Downes \& T. Pollard. Glasgow: Cruithne Press, 69-93.

Bourdieu, P., 1977. Outline of a Theory of Practice. Cambridge: Cambridge University Press.

Brewster, T.C.M., 1976. Garton Slack. Current Archaeology 51, 104-16.

Brewster, T.C.M., 1982. The Excavation of Garton and Wetwang Slacks. London: National Monuments Record (microfiche).

Britnell, W., 1989. Collfryn hill enclosure. Proceedings of the Prehistoric Society 55, 89-134. 
Buckley, D.G. \& J. Hedges, 1988. The Bronze Age and Saxon Settlement at Springfield Lyons, Essex: an Interim Report. (Occasional Paper 5.) Chelmsford: Essex County Council Archaeology Section.

Campbell, E., 1991. Excavations of a wheelhouse and other Iron Age structures at Sollas, North Uist, by R.J.C. Atkinson in 1957. Proceedings of the Society of Antiquaries of Scotland 121, 117-73.

Champion, T.C., 1980. Settlement and environment in Later Bronze Age Kent, in Settlement and Society in the British Later Bronze Age, eds. J.C. Barrett \& R. Bradley. (BAR British Series 83.) Oxford: BAR, 223-46.

Champion, T.C. \& J.R. Collis (eds.), 1996. The Iron Age in Britain and Ireland: Recent Trends. Sheffield: Sheffield Academic Press.

Chapman, R., I. Kinnes \& K. Randsborg, 1981. The Archaeology of Death. Cambridge: Cambridge University Press.

Coles, J.M. \& S. Minnitt, 1995. Industrious and Fairly Civilized: the Glastonbury Lake Village. Exeter: Somerset Levels Project and Somerset County Council.

Cunliffe, B.W., 1991. Iron Age Communities in Britain. 3rd edition. London: Routledge.

Cunliffe, B.W., 1993. Danebury. London: Batsford and English Heritage.

Cunliffe, B.W., 1995. Iron Age Britain. London: Batsford and English Heritage.

Cunliffe, B.W., 1996. Danebury: an Iron Age Hillfort in Hampshire, vol. 6: A Hillfort Community in Perspective. (CBA Research Report 102.) London: Council for British Archaeology.

Dent, J.S., 1982. Cemeteries and settlement patterns of the Iron Age on the Yorkshire Wolds. Proceedings of the Prehistoric Society 48, 437-57.

Dent, J.S., 1983. A summary of the excavations carried out in Garton Slack and Wetwang Slack, 1964-80. East Riding Archaeologist 7, 1-14.

Dodgshon, R.A., 1985. Symbolic classification and the development of early Celtic landscape, in Duality, ed. E. Lyle. Edinburgh: Traditional Cosmology Society.

Fairhurst, H., 1971. The wheelhouse site at A'Cheardach Bheag on Drimore machair. Glasgow Archaeological Journal 2, 72-110.

Fasham, P.J., 1985. The Prehistoric Settlement at Winnall Down, Winchester. (Monograph 2.) Winchester: Hampshire Field Club.

Fasham, P.J., D.E. Farwell \& R.J.B. Whinney, 1989. The Archaeological Site at Easton Lane, Winchester. (Monograph 6.) Winchester: Hampshire Field Club.

Fitzpatrick, A., 1994. Outside in: the structure of an Early Iron Age house at Dunston Park, Thatcham, Berkshire, in Fitzpatrick \& Morris (eds.), 68-72.

Fitzpatrick, A., 1997. Everyday life in Iron Age Wessex, in Gwilt \& Haselgrove (eds.), 73-86.

Fitzpatrick, A. \& E. Morris (eds.), 1994. The Iron Age in Wessex: Recent Work. Salisbury: Trust for Wessex Archaeology.

Frazer, J.G., 1911. The Golden Bough: a Study in Magic and Religion, part III: The Dying God. London: Macmillan.

Giddens, A., 1984. The Constitution of Society: Outline of the
Theory of Structuration. London: Polity.

Giles, M. \& M. Parker Pearson, in press. Learning to live in the Iron Age: dwelling and praxis, in Northern Exposure: the Iron Age in Northern Britain., ed. W. Bevan. Leicester: Leicester University Press.

Gilmour, S. \& M. Cook, 1998. Excavations at Dun Vulan: a reinterpretation of the reappraised Iron Age. Antiquity 72, 327-37.

Gingell, C., 1982. The excavation of an Iron Age enclosure at Groundwell Farm. Wiltshire Archaeological Magazine 76, 33-75.

Green, M., 1992. Animals in Celtic Life and Myth. London: Routledge.

Guilbert, G., 1982. Post-ring symmetry in roundhouses at Moel $Y$ Gaer and some other sites in prehistoric Britain, in Structural Reconstruction, ed. P.J. Drury. (BAR British Series 110.) Oxford: BAR, 67-86.

Gwilt, A., 1997. Popular practices from material culture: a case study of the Iron Age settlement at Wakerley, in Gwilt \& Haselgrove (eds.), 153-66.

Gwilt, A. \& C. Haselgrove (eds.), 1997. Reconstructing Iron Age Societies: New Approaches to the British Iron Age. (Oxbow Monograph 71.) Oxford: Oxbow.

Hawkes, S., 1994. Longbridge Deverill Cow Down, Wiltshire, House 3: a major round house of the Early Iron Age. Oxford Journal of Archaeology 13, 49-69.

Hedges, J.W., 1987. Bu, Gurness and the Brochs of Orkney. (BAR British Series 163.) Oxford: BAR.

Hill, J.D., 1996. Hill-forts and the Iron Age of Wessex, in Champion \& Collis (eds.), 95-116.

Hingley, R., 1989. Rural Settlement in Roman Britain. London: Seaby.

Hingley, R., 1990a. Domestic organisation and gender relations in Iron Age and Romano-British households, in The Social Archaeology of the House, ed. R. Samson. Edinburgh: Edinburgh University Press, 125-48.

Hingley, R., 1990b. Iron Age 'currency bars': the archaeological and social context. Archaeological Journal 147, 91-117.

Hingley, R., 1997. Iron, ironworking and regeneration: a study of the symbolic meaning of metalworking in Iron Age Britain, in Gwilt \& Haselgrove (eds.), 9-18.

James, S. \& V. Rigby, 1997. Britain and the Celtic Iron Age. London: British Museum Press.

Jensen, J., 1993. Prehistory of Denmark. Copenhagen: National Museum of Denmark.

King, A., 1991. Food production and consumption - meat, in Roman Britain: Recent Trends, ed. R.F.J. Jones. Sheffield: Sheffield Academic Press, 15-20.

Lévi-Strauss, C., 1968. Structural Anthropology. London: Penguin.

Lewis, G., 1980. Day of Shining Red: an Essay on Understanding Ritual. Cambridge: Cambridge University Press.

Maltby, M., 1994. Animal exploitation in Iron Age Wessex, in Fitzpatrick \& Morris (eds.), 9-10.

Maltby, M., 1996. The exploitation of animals in the Iron Age: the archaeozoological evidence, in Champion \& Collis (eds.), 17-27. 
Manby, T.G. 1986. Thwing: Excavation and Field Archaeology in East Yorkshire. Unpublished interim report.

Megaw, R. \& V. Megaw, 1997. Do the ancient Celts still live? An essay on identity and contextuality. Studia Celtica 31, 107-23.

Meniel, P., 1987. Chasse et élevage chez les Gaulois. Paris: Errance.

Metcalf, P. \& R. Huntington, 1991. Celebrations of Death: the Anthropology of Mortuary Ritual. 2nd edition. Cambridge: Cambridge University Press.

Oswald, A., 1997. A doorway on the past: practical and mystic concerns in the orientation of roundhouse doorways, in Gwilt \& Haselgrove (eds.), 87-95.

Pader, E-J., 1982. Symbolism, Social Relations and the Interpretation of Mortuary Remains. (BAR Supplementary Series 130.) Oxford: BAR.

Parker Pearson, M., 1993. The powerful dead: archaeological relationships between the living and the dead. Cambridge Archaeological Journal 3(2), 203-29.

Parker Pearson, M., 1996. Food, fertility and front doors: houses in the first millennium $\mathrm{BC}$, in Champion \& Collis (eds.), 117-32.

Parker Pearson, M. \& C. Richards, 1994a. Architecture and order: spatial representation and archaeology, in Architecture and Order: Approaches to Social Space, eds. M. Parker Pearson \& C. Richards. London: Routledge, 38-72.

Parker Pearson, M. \& C. Richards, 1994b. Ordering the world: perceptions of architecture, space and time, in Architecture and Order: Approaches to Social Space, eds. M. Parker Pearson \& C. Richards. London: Routledge, 1-37.

Parker Pearson, M., N. Sharples \& J.A. Mulville, 1996. Brochs and Iron Age society: a reappraisal. Antiquity 70, 57-67.

Parker Pearson, M. \& N. Sharples, with J. Mulville \& H. Smith, 1999. Between Land and Sea: Excavations at Dun Vulan. Sheffield: Sheffield Academic Press.

Parker Pearson, M., J.A. Mulville, N. Sharples \& H. Smith, in press. Decoding dirt and deposition: the Iron Age broch settlement of Dun Vulan, Outer Hebrides,
Scotland, in L'Age du Fer sur la Manche: l'Habitat et l'Occupation du Sol en Europe, ed. J.R. Collis. Sheffield: Sheffield Academic Press.

Reid, M.L., 1989. A room with a view: an examination of round-houses, with particular reference to northern Britain. Oxford Journal of Archaeology 8, 1-39.

Robinson, T., 1986. Stones of Aran: pilgrimage. Harmondsworth: Penguin.

Ross, A., 1967. Pagan Celtic Britain. London: Routledge \& Kegan Paul.

Scott, W.L., 1948. Gallo-British colonies: the aisled roundhouse culture in the North. Proceedings of the Prehistoric Society 14, 46-125.

Sharples, N., 1991. Maiden Castle: Excavation and Field Survey 1985-6. London: English Heritage.

Stead, I.M., 1979. The Arras Culture. York: Yorkshire Philosophical Society.

Stead, I.M., 1991. Iron Age Cemeteries in East Yorkshire. London: English Heritage.

Tierney, J.J., 1960. The Celtic ethnography of Poseidonius. Proceedings of the Royal Irish Academy 60 (Section C), 189-275.

Wainwright, G.J., 1979. Gussage All Saints: an Iron Age Settlement in Dorset. London: HMSO.

Wait, G., 1985. Ritual and Religion in Iron Age Britain. (BAR British Series 149.) Oxford: BAR.

Whimster, R., 1981. Burial Practices in Iron Age Britain. (BAR British Series 90.) Oxford: BAR.

Whitehouse, R. \& D. Whitehouse, 1974. The fauna, in Croft Ambrey, by S.C. Stanford. Hereford: privately printed, 215-21.

Williams, R.J. \& R.J. Zeepvat, 1994. Bancroft: a Late Bronze Age/Iron Age Settlement, Roman Villa and Temple Maulsoleum, vol. 1: Excavations and Building Materials. (Monograph 7.) Aylesbury: Buckinghamshire Archaeological Society.

Young, A., 1953. An aisled farmhouse at the Allasdale, Isle of Barra. Proceedings of the Society of Antiquaries of Scotland 87, 80-105.

Young, A. \& K.M. Richardson, 1960. A'Cheardach Mhor, Drimore, South Uist. Proceedings of the Society of Antiquaries of Scotland 93, 135-73. 